\title{
Upgrading of Oils from Biomass and Waste: Catalytic Hydrodeoxygenation
}

\author{
Mai Attia ${ }^{1,2, *}$, Sherif Farag $1,3,4$ (1) and Jamal Chaouki ${ }^{1,4, *}$ \\ 1 Department of Chemical Engineering, Polytechnique Montreal, Montreal, QC H3C 3A7, Canada; \\ sherif.farag@um6p.ma \\ 2 GreeNovel Inc., Saint-Constant, QC J5A 0J5, Canada \\ 3 Faculty of Engineering, Helwan University, Cairo 11231, Egypt \\ 4 TechCell Department, Mohammed VI Polytechnic University, Ben Guerir 43150, Morocco \\ * $\quad$ Correspondence: mai.attia@polymtl.ca (M.A.); jamal.chaouki@polymtl.ca (J.C.); Tel.: +1-438-878-3606 (M.A.); \\ +1-514-340-4711 (ext. 4034) (J.C.)
}

Received: 23 August 2020; Accepted: 20 November 2020; Published: 26 November 2020

\begin{abstract}
The continuous demand for fossil fuels has directed significant attention to developing new fuel sources to replace nonrenewable fossil fuels. Biomass and waste are suitable resources to produce proper alternative fuels instead of nonrenewable fuels. Upgrading bio-oil produced from biomass and waste pyrolysis is essential to be used as an alternative to nonrenewable fuel. The high oxygen content in the biomass and waste pyrolysis oil creates several undesirable properties in the oil, such as low energy density, instability that leads to polymerization, high viscosity, and corrosion on contact surfaces during storage and transportation. Therefore, various upgrading techniques have been developed for bio-oil upgrading, and several are introduced herein, with a focus on the hydrodeoxygenation (HDO) technique. Different oxygenated compounds were collected in this review, and the main issue caused by the high oxygen contents is discussed. Different groups of catalysts that have been applied in the literature for the HDO are presented. The HDO of various lignin-derived oxygenates and carbohydrate-derived oxygenates from the literature is summarized, and their mechanisms are presented. The catalyst's deactivation and coke formation are discussed, and the techno-economic analysis of HDO is summarized. A promising technique for the HDO process using the microwave heating technique is proposed. A comparison between microwave heating versus conventional heating shows the benefits of applying the microwave heating technique. Finally, how the microwave can work to enhance the HDO process is presented.
\end{abstract}

Keywords: oil upgrading; biomass; waste; hydrodeoxygenation

\section{Introduction}

In light of the fast-growing global energy demand, depletion of fossil fuels, and associated detrimental environmental issues, it is of the utmost significance to find alternative renewal energy resources to meet the energy demand. The environmental challenge caused by global warming has focused most of the research in recent years to convert biomass and waste into chemicals and transportation fuels [1]. Although there are several forms of renewable energy, such as wind and solar power, that contribute increasingly to the energy supply, liquid fuel remains the essential source of energy for various sectors and, in particular, the transportation sector.

Biofuel can be produced from several feedstocks that are widely available in all countries, especially industrialized ones, and the most important feedstocks are biomass and west. Biomass plants mainly consist of cellulose, hemicellulose, and lignin [2-4]. Several factors affect the characteristics and the percentage of the biomass components into the plants, such as the age of the plant, the place where the 
plant was growing, etc., [4]. It was demonstrated that cellulose exists in the biomass with 35-45 wt.\%, hemicellulose with 25-30 wt.\%, and lignin with 20-35 wt.\% [4-7]. Hemicellulose is the weakest component if exposed to degradation because of the large numbers of branches compared to other components. Cellulose is much stronger than hemicellulose because the long polymers in cellulose with side changes enhance the bonds' strength. The complex structure of lignin, which mainly consists of a large number of aromatics with side chains, makes it the most substantial component and has a high resistance to decomposition if compared with cellulose and hemicellulose [4,8-11]. Biomass can produce first and second generations of biofuels. The first-generation biofuels or the original biofuels are produced from palatable food crops (for example, sugarcane, wheat, grain, corn, potato, soybean, sunflower, and coconut). The second-generation biofuels are produced from various agriculture and forest feedstocks (mainly the lignocellulosic materials), building waste, industrial waste, and municipal waste $[12,13]$. Third-generation biofuel is usually derived from alga. Indeed, biomass and waste pose a significant danger to the environment, and their disposal creates a serious issue. Therefore, converting them into a useful biofuel is a promising proposition to lessen their dangerous effect and help solve their disposal problem [14].

Liquid fuels can be produced from biomass and waste through gasification to produce syngas, pyrolysis to produce bio-oil, and hydrolysis to produce aqueous sugar [14], Figure 1. Owing to the high bio-oil yield and economic efficiency, pyrolysis has been regarded as the most effective conversion technology to produce liquid biofuel from biomass and waste. Pyrolysis-produced bio-oil usually contains various chemical compounds, including carboxylic acids, aldehydes, ketones, furans, aliphatic and aromatic hydrocarbons, phenolics, and sugars.

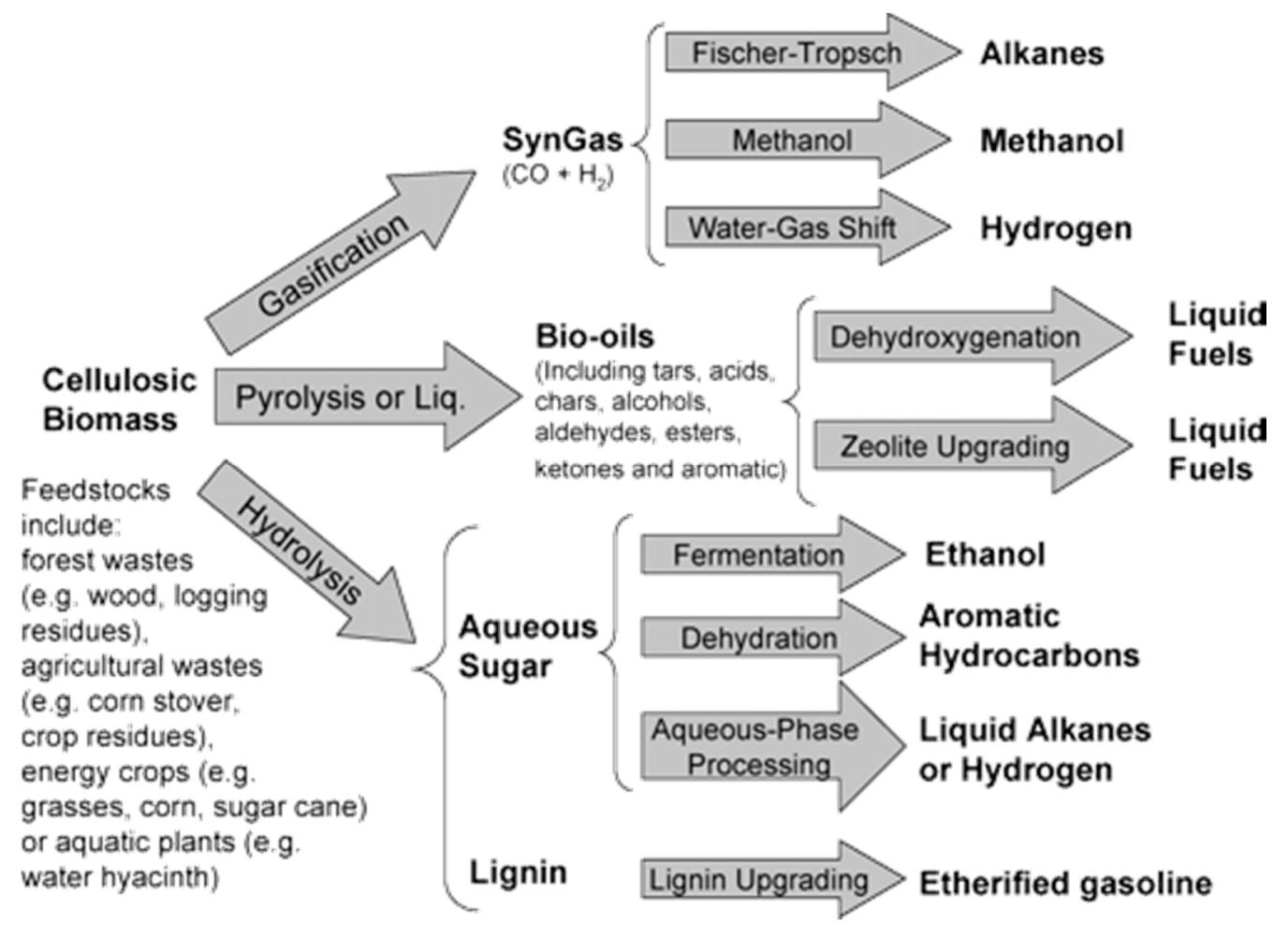

Figure 1. Different routes for fuel production from biomass. Reprinted from reference [15].

Pyrolysis is the thermal cracking of carbonaceous material into lower density components in the absence of oxygen. The thermal degradation of the biomass leads to the production of charcoal (solid), bio-oil (liquid) and syngas (gaseous) energy products. Pyrolysis, based on the operating conditions, can be classified under three main categories [16]: 
- Conventional Pyrolysis: Pyrolysis at the slow heating rate, which permits the formation of the solid, liquid and gaseous products in significant portions.

- Fast Pyrolysis: If the procedure aims to produce a liquid or gaseous product, fast pyrolysis is employed. In this case, the products are considered marginal with a low yield. The operating conditions are declared: High operating temperature, short residence time and very fine particles.

- Flash Pyrolysis: In this method, the feedstock is directly fed into the high-temperature zone of the reactor, which subsequently undergoes flash pyrolysis where the final products are in the gaseous phase with a short contact time inside the reactor.

Pyrolysis in the forms of flash or fast pyrolysis is employed during the gasification process correspondingly. Three methods are employed to raise the wanted products' yield: Steam reforming of the pyrolysis liquids, tar removal and maintaining the operating temperature around $700{ }^{\circ} \mathrm{C}$ and using a catalyst at temperatures below $750{ }^{\circ} \mathrm{C}$. Table 1 compares the operating conditions of different pyrolysis methods.

Table 1. Operating Conditions of different pyrolysis processes [16].

\begin{tabular}{cccc}
\hline & Conventional & Fast & Flash \\
\hline Pyrolysis Temperature (K) & $550-950$ & $850-1250$ & $1050-1300$ \\
Heating Rate (K/s) & $0.1-1$ & $10-200$ & $>1000$ \\
Particle Size (mm) & $5-10$ & $<1$ & $<0.2$ \\
Solid Residence Time (s) & $450-550$ & $0.5-10$ & $<0.5$ \\
\hline
\end{tabular}

It is worth mentioning that great attention is directed to the fast pyrolysis process for bio-oil production from biomass. This aspect's main reason is the high liquid yield produced with specific characterizations that make it has unique advantages in transport, storage, combustion, retrofitting, and flexibility in production and marketing [17].

Unfortunately, upgrading bio-oil produced from the pyrolysis process is essential due to the high content of hazardous materials and bio-oil properties if compared with the fuel oil. Bio-oil has a high water content (15-30 wt.\%), a low corrosive $\mathrm{pH}(<3)$, a higher oxygen content (35-40 wt.\%), and a higher heating value (HHV) of 16-19 MJ/kg [18], and hazard materials such as S-compounds, metals, $\mathrm{N}$-compounds, and a high content of oxygenated compounds [19]. Sulfur is emitting to the atmosphere in the form of $\mathrm{SO}_{x}$, causing acid rain formation through its reaction with water, oxygen, and other chemicals in the atmosphere. The presence of sulfur in oil increases corrosion issues during the refinery process but helps in the deactivation of the catalyst in minimal time. The removal of dibenzothiophene and its alkyl derivatives is a big challenge, as the compounds cannot be transferred into $\mathrm{H}_{2} \mathrm{~S}$ due to the steric hindrance adsorption on the surface of the catalyst [20]. Also, $\mathrm{NO}_{x}$ emits into the atmosphere and poisons the catalyst during the refinery process. Metals in the oil enhance the production of high volumes of coke and dry gases and decrease the liquid output [21]. In addition, the metals enhance the fast catalyst deactivation [21,22], which is mainly due to the deposition of metal oxides formed on the pore of the catalyst and blocking the active site. The presence of oxygenates in the bio-oil results in several technical challenges when using bio-oil as the "drop-in fuel," like low energy density, instability, high viscosity, and corrosion post-processing to remove oxygen atoms from bio-oil must be carried out [23]. Table 2 shows the elemental analysis of different biomass feedstocks.

Even though there is a wide range of upgrading techniques that have been investigated for the fast pyrolysis-produced bio-oil, hydrotreatment (e.g., hydrodeoxygenation, hydrodesulfurization, hydrodemetallization, and hydrodenitrogenation) has been employed in oil refineries for many years, and the process is well-established [24]. Among the hydrotreatment techniques, catalytic hydrodeoxygenation (HDO) is a compelling upgrading approach to produce petroleum-like hydrocarbon fuels or chemical building blocks from fast pyrolysis-produced bio-oil, during which oxygen present in the bio-oil is removed through water formation [25]. 
In this review article, the different upgrading techniques of bio-oil were discussed, catalytic hydrodeoxygenation of different compounds derived from the pyrolysis oil of biomass and waste, the mechanism of the HDO, the various families of catalysts used for HDO, different catalysts that have been applied for the HDO process, the issue of the deactivation of catalysts, and the techno-economic aspects of the HDO process. Different deoxygenation approaches for bio-oil.

Table 2. Typical elemental analysis for different biomass materials (wt.\%) $[11,25,26]$.

\begin{tabular}{cccccc}
\hline Material & C & H & O & N & S \\
\hline Ash & 49.7 & 6.9 & 3.0 & - & - \\
Beech & 51.6 & 6.3 & 41.4 & - & - \\
Sawdust & 48.3 & 6.22 & 45.2 & 0.22 & 0 \\
Barley Straw & 45.7 & 6.1 & 38.3 & 0.4 & 0.1 \\
Bituminous Coal & 73.1 & 5.5 & 8.7 & 1.4 & 1.7 \\
Cypress & 55.0 & 6.5 & 38.1 & - & - \\
Kraft lignin & 63.3 & 5.8 & 29.2 & 0.1 & 1.6 \\
Miscanthus & 48.1 & 5.4 & 42.2 & 0.5 & $<0.1$ \\
Rice Straw & 41.4 & 5 & 39.9 & 0.7 & 0.1 \\
Wood & 51.6 & 6.3 & 41.5 & - & 0.1 \\
Wheat Straw & 48.5 & 5.5 & 3.9 & 0.3 & 0.1 \\
Material & $\mathrm{C}$ & $\mathrm{H}$ & $\mathrm{O}$ & $\mathrm{N}$ & $\mathrm{S}$ \\
\hline
\end{tabular}

\subsection{Oxygenated Compounds Exist in Biomass Pyrolysis Oil}

The bio-oil compositions produced from the biomass pyrolysis are very complex and contain predominantly water and hundreds of different chemical compounds, which include various aldehydic compounds, esters, phenols, sugar, acids, ketones, lignin-derived compounds, alcohols, and more compounds. Other compounds that have been detected in the rice husk-based biomass pyrolysis oil can be seen in Table 3 .

Table 3. Different oxygenated compounds exist in biomass pyrolysis oil [26].

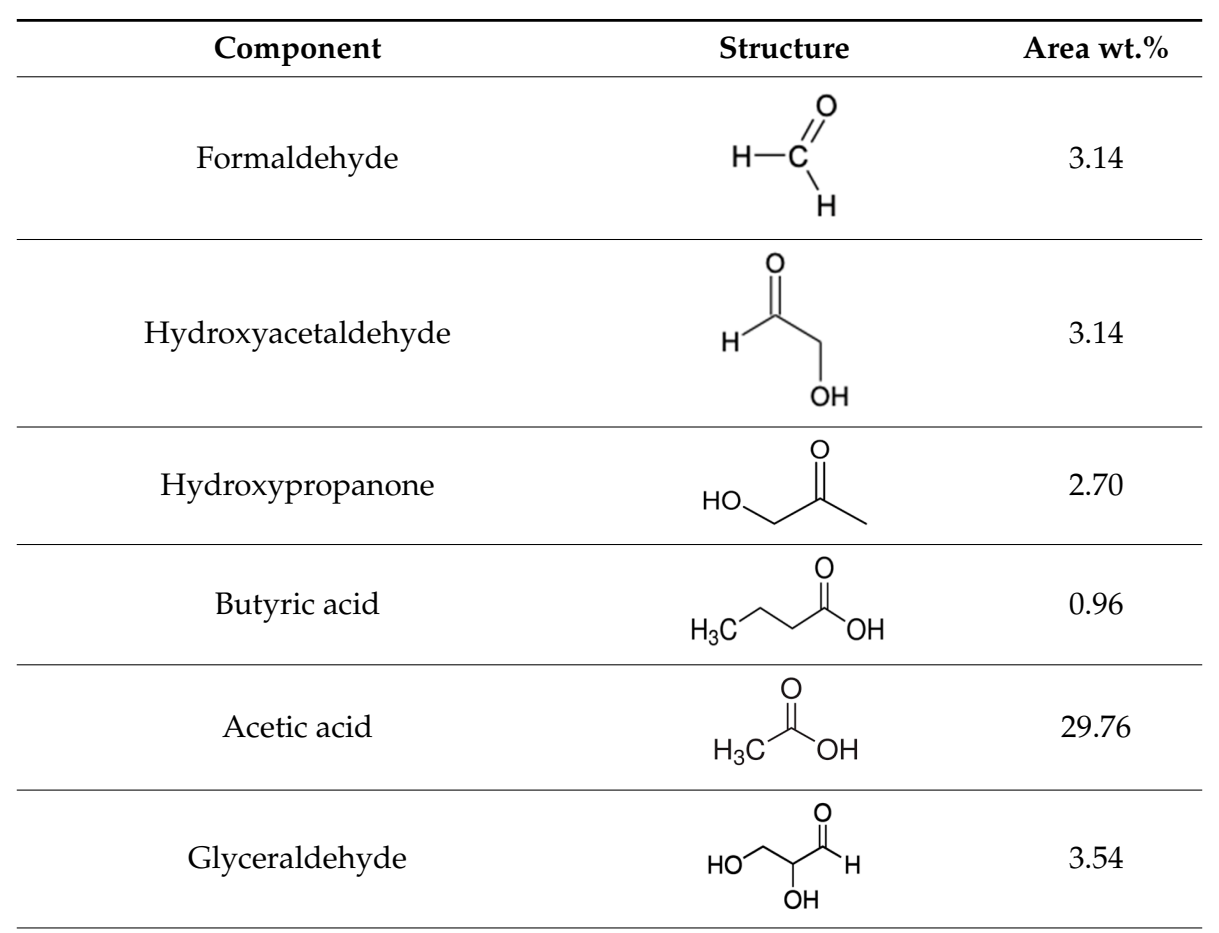


Table 3. Cont.

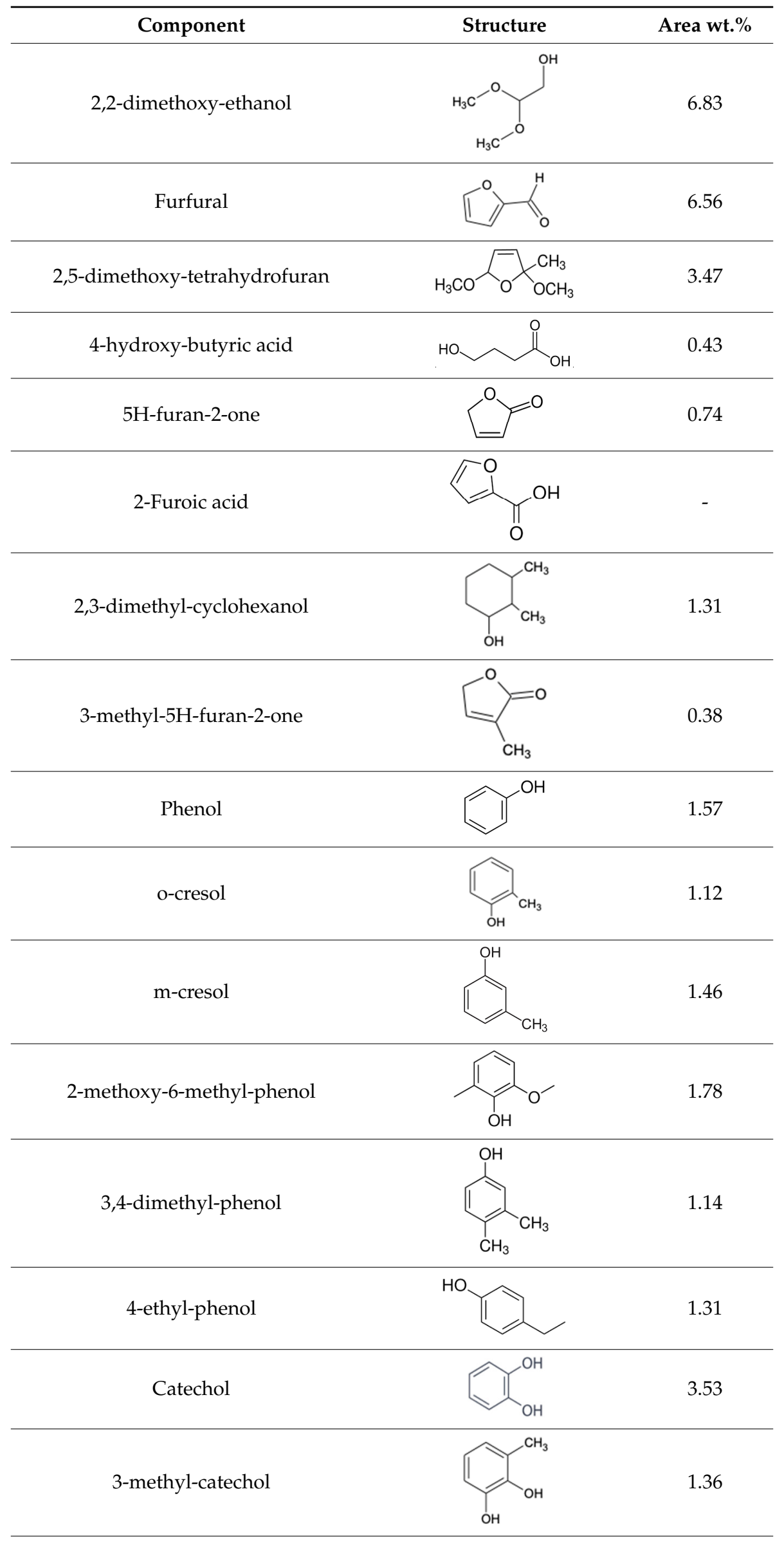


Table 3. Cont.

\begin{tabular}{|c|c|c|}
\hline Component & Structure & Area wt. $\%$ \\
\hline Vanillin & & 0.24 \\
\hline 4-ethyl-catechol & & 0.71 \\
\hline Levoglucosan & & 9.95 \\
\hline 2,3,4-trimethoxy-benzaldehyde & & 0.20 \\
\hline 3-(4-hydroxy-2-methoxy-phenyl)-propenal & & 0.15 \\
\hline
\end{tabular}

\subsection{Issues Related to the Presence of Oxygen in the Feedstock or Products}

The bio-oil properties obtained from fast pyrolysis are presented in Table 4, as shown below [27]. As indicated in the table, bio-oil often contains around 30-45 wt.\% of oxygen, thereby leading to a significantly higher heating value (HHV) of $16-19 \mathrm{MJ} / \mathrm{kg}$ compared to that of heavy fuel $(40 \mathrm{MJ} / \mathrm{kg}$ ). Another problem relating to the high oxygen content in bio-oil is the low $\mathrm{pH}$ value (i.e., 2-4), which makes bio-oil an undesirable corrosive property. Besides, bio-oil is highly viscous, and it is not chemically-stable upon storage, which is attributed to the series of reactions, like oligomerization and polymerization, occurring between the different oxygenated functionalities [28].

Table 4. The major physiochemical properties of bio-oil obtained from fast pyrolysis [27].

\begin{tabular}{|c|c|c|}
\hline Properties & Bio-Oil from Fast Pyrolysis & Heavy Fuel \\
\hline Water (wt.\%) & $15-30$ & 0.1 \\
\hline $\mathrm{pH}$ & $2-4$ & - \\
\hline Density $\left(\mathrm{kg} / \mathrm{m}^{3}\right)$ & 1200 & 940 \\
\hline \multicolumn{3}{|c|}{ Elemental composition (wt.\%) } \\
\hline $\mathrm{C}$ & $48-65$ & $83-86$ \\
\hline $\mathrm{H}$ & $5.5-7$ & $11-14$ \\
\hline $\mathrm{O}$ & $30-45$ & $<1$ \\
\hline $\mathrm{N}$ & $0-0.3$ & $<0.3$ \\
\hline S & $<0.05$ & $<3.0$ \\
\hline $\mathrm{HHV}(\mathrm{MJ} / \mathrm{kg})$ & $16-19$ & 40 \\
\hline Viscosity $\left(\mathrm{cP}, 50^{\circ} \mathrm{C}\right)$ & $40-100$ & 180 \\
\hline Ash (wt.\%) & $0-0.2$ & 0.1 \\
\hline Solids (wt.\%) & $0.2-1$ & 1 \\
\hline Distillation residue (wt.\%) & $<50$ & 1 \\
\hline $\mathrm{NO}_{x}$ emission & $<0.7$ & 1.4 \\
\hline $\mathrm{SO}_{x}$ emission & 0 & 0.28 \\
\hline
\end{tabular}




\section{Different Deoxygenation Approaches for Bio-Oil}

A wide range of upgrading methods has been developed for fast pyrolysis bio-oil. Such techniques can be generally categorized into physical and chemical techniques, as depicted in Figure 2 [29].

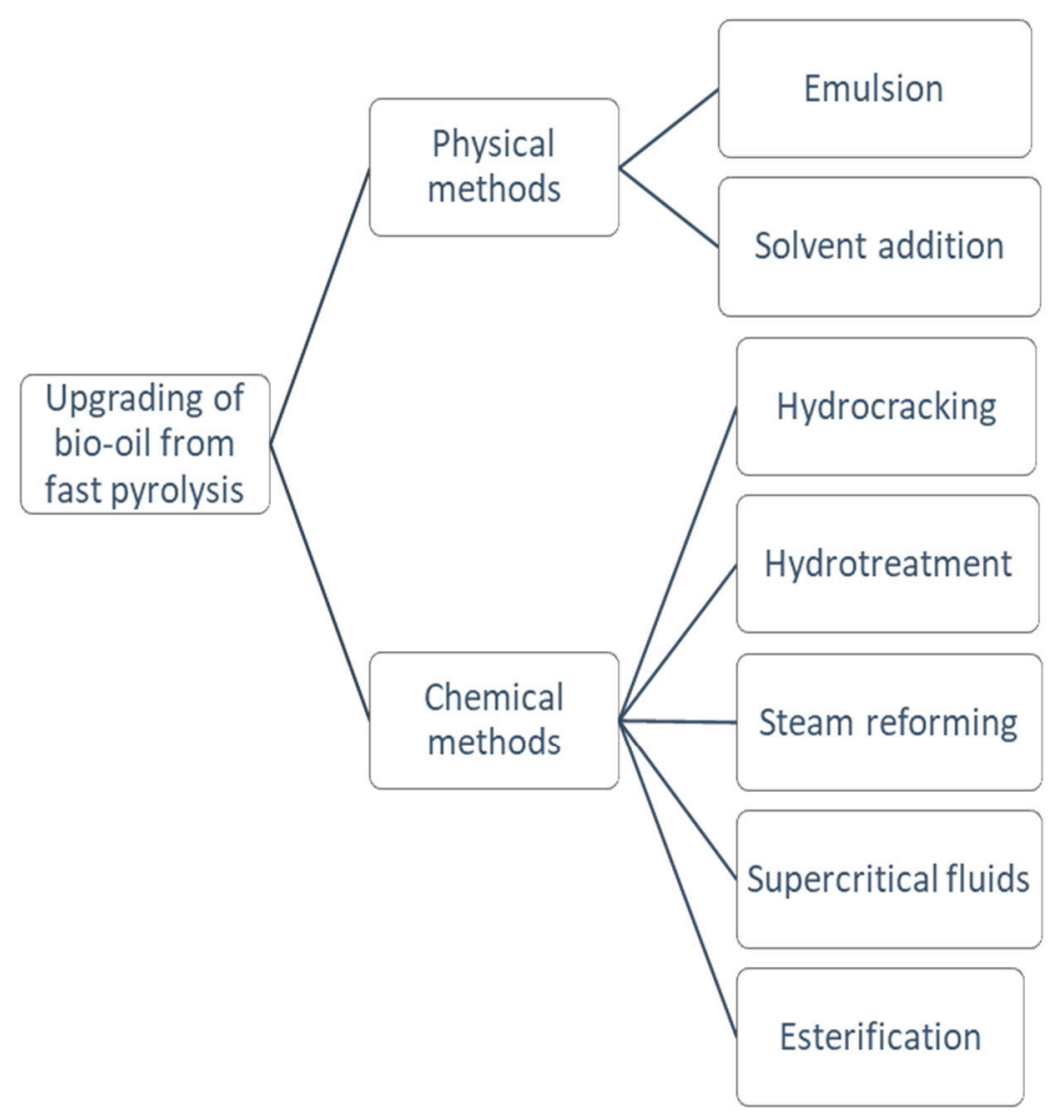

Figure 2. The major upgrading approaches applied for the bio-oil obtained from fast pyrolysis [29].

\subsection{Physical Upgrading Technologies}

\subsubsection{Solvent Addition}

Solvent extraction is a simple upgrading approach for fast pyrolysis bio-oil, in which polar solvents (e.g., ethanol, methanol, ethyl acetate, and acetone) are added to crude bio-oil to reduce its viscosity and improve the homogeneity and energy density. As indicated by Khosravanipour et al. [30], the use of methanol is reported to lower the bio-oil's viscosity by 20-fold. Liu et al. [31] explored the effect of acetone addition on the physicochemical properties of bio-oil from the fast pyrolysis of pinewood sawdust in a fluidized bed reactor, and it was found that the $\mathrm{pH}$ value of bio-oil increased, and the water content and viscosity decreased. The authors also stated that acetone's presence showed an inhibiting impact on the aging reaction of bio-oil and introducing new chemical compounds. However, this upgrading technique does not help eliminate undesirable compounds, such as oxygenates, from the bio-oil.

\subsubsection{Emulsion}

Emulsion, as another easy-operation upgrading method, has been investigated for the bio-oil obtained from fast pyrolysis. In the emulsion treatment, fast pyrolysis bio-oil is blended with other diesel fuels or biodiesel with the addition of surfactant to enhance its ignition properties. For instance, Jiang and Ellis [32] performed a parametric study for upgrading bio-oil from softwood by biodiesel-assisted emulsion and the use of octanol as the surfactant, and the optimal reaction 
conditions were 4 vol. $\%$ of surfactant dosage, a bio-oil/biodiesel ratio of $4 / 6 \mathrm{vol} . \%$ a stirring speed of $1200 \mathrm{rpm}$, a processing time of $15 \mathrm{~min}$, and a temperature of $30^{\circ} \mathrm{C}$. At these optimized conditions, the viscosity, acidity, and water content of softwood-derived bio-oil were considerably reduced after the emulsion treatment. Even though emulsion is a simple upgrading technique, the high-cost of surfactant, high energy consumption, and the inability to remove unfavourable chemical substances of bio-oil limit its large-scale application [33].

\subsection{Chemical Upgrading Technologies}

\subsubsection{Esterification}

Esterification is a relatively simple chemical method often carried out at moderate conditions to upgrade bio-oil where the addition of alcohol is needed. Among all the investigated alcohols, methanol is the most commonly used solvent. The main reactions occurring between bio-oil from fast pyrolysis and alcohol are shown in Figure 3 [34].<smiles>[R]O[I-]</smiles>

Carboxylic acid<smiles>[R]C([R])=O</smiles>

Aldehyde/Ketone<smiles></smiles>

Alcohol
Alcohol<smiles>[R]C(=O)O[18OH]</smiles>

Ester

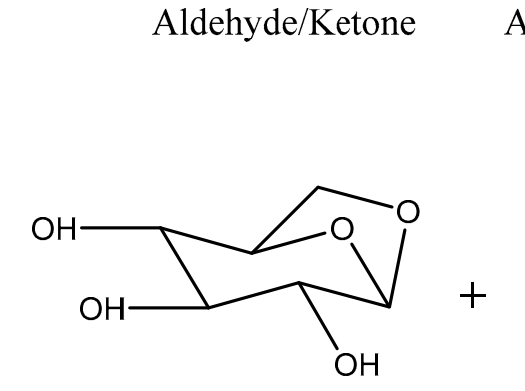

Levoglucosan<smiles>[R]O[W]</smiles>

Alkyl D-glycopyranoside

Figure 3. The main reactions occurring between bio-oil and alcohol during esterification treatment. Reprinted from reference [34].

Previously, Weerachanchai et al. [35] investigated the upgrading of palm shell-derived bio-oil by esterification under varying reaction conditions, and the authors reported that the use of Amberlyst 15 as the catalyst was helpful to promote the conversion of carboxylic acids in the bio-oil to their corresponding alcohols and simultaneously reduce the concentration of aldehydes in the bio-oil. However, the heating value of upgraded bio-oil ranged from 23 to $25 \mathrm{MJ} / \mathrm{kg}$ and thus, further boosting treatment is still required. In summary, esterification offers several advantages of mild reaction conditions, cheap alcohol price, and easy-operation; however, its ineffectiveness in removing nitrogen-containing compounds makes it impractical to upgrade algae-derived bio-oil owing to the presence of highly concentrated nitrogenates in the bio-oil [24]. 


\subsubsection{Supercritical Fluid}

In recent years, supercritical fluid has been widely applied as an alternative upgrading approach for fast pyrolysis bio-oil, which accounts for the inherent benefits of supercritical fluid, such as liquid-like density, gas-like diffusivity and viscosity, and high mass and heat transfer rates [36]. For example, Lee et al. [37] catalytically upgrade the bio-oil obtained from the fast pyrolysis of woody biomass by the supercritical catalytic fluid at $250-350{ }^{\circ} \mathrm{C}$ with the use of a Ni-based catalyst. It was found that the highest upgraded bio-oil yield of $70.5 \mathrm{wt} . \%$ was obtained at $350^{\circ} \mathrm{C}$ with $\mathrm{MgNiMo} / \mathrm{AC}$, which was accompanied by the lowest $\mathrm{O} / \mathrm{C}$ molar ratio of 0.19 , total acid number (TAN) of $6.2 \mathrm{mg}$ $\mathrm{KOH} / \mathrm{g}$, and higher heating value (HHV) of $33.4 \mathrm{MJ} / \mathrm{kg}$. According to the Gas chromatography Mass Spectrometry GC-MS analysis results, the undesirable oxygen-containing compounds, such as carboxylic acids, aldehydes, and levoglucosan, were largely removed from the bio-oil after upgrading. Despite that, the acidity and viscosity can be reduced, and the supercritical fluid can improve the energy content of bio-oil; a high-pressure resistant reactor is needed, and the corrosion of material at supercritical conditions cannot be neglected.

\subsubsection{Steam Reforming}

Steam reforming of fast pyrolysis bio-oil is an effective way to produce $\mathrm{H}_{2}$-rich syngas [38]. This approach is usually used at high temperatures of $700-1000{ }^{\circ} \mathrm{C}$ with the use of a Ni-based catalyst. Lan P et al. [39] catalytically upgraded the bio-oil obtained from the fast pyrolysis of a rice husk by steam reforming, and it was reported that the highest $\mathrm{H}_{2}$ yield of 75.88 was achieved at $700-800{ }^{\circ} \mathrm{C}$, a steam/carbon molar ratio of 15-20, and a liquid hourly space velocity of $0.5-1.0 \mathrm{~h}^{-1}$. Although highly energy-dense $\mathrm{H}_{2}$ can be generated from the steam reforming of bio-oil, there is a requirement for using a high-temperature resistant reactor.

\subsubsection{Hydrocracking}

The hydrocracking process is one of the upgrading processes that involves cracking the heavy molecular feeds into smaller valuable products. The process involves a two-step reaction: (1) the first step is the catalytic cracking of the high molecular weight compounds, and (2) the second is the hydrogenation reaction of the cracked molecules. A higher temperature of $300-500{ }^{\circ} \mathrm{C}$ and pressure of 10-20 MPa is often applied for hydrocracking over a heterogeneous catalyst, in which an organic liquid, a water phase, gas, and coke are commonly generated as the main products. The general reaction pathway for hydrocracking is shown in Figure 4 [40].

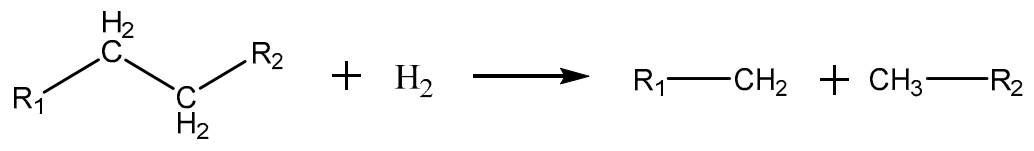

Figure 4. The general reaction pathway for hydrocracking. Reprinted from reference [40].

Tanneru and Steele [41] have studied the influences of reaction temperature, $\mathrm{H}_{2}$ pressure, residence time, and catalyst type on the hydrocracking of bio-oil obtained from the fast pyrolysis of pinewood chips to produce hydrocarbons. The resulting hydrocarbon mixture contained an HHV of $43.6 \mathrm{MJ} / \mathrm{kg}$, the oxygen content of $0.5 \mathrm{wt} . \%$, and TAN of $0.3 \mathrm{mg} \mathrm{KOH} / \mathrm{g}$, along with the density and viscosity of $0.9 \mathrm{~g} / \mathrm{mL}$ and $1.8 \mathrm{cSt}$, respectively. Although the light components can be produced by hydrocracking, the need for a high operating temperature and high-pressure $\mathrm{H}_{2}$ could significantly increase the entire process's cost.

In conclusion, due to the hydrotreatment upgrading approach's maturity, the catalyst, technical challenges, reactor configuration, and economics of HDO are discussed in the following sections. 


\subsubsection{Hydrotreatment}

Hydrotreatment is a well-established process in oil refineries that are often carried out at moderate temperatures of $300-450{ }^{\circ} \mathrm{C}$ and $\mathrm{H}_{2}$ pressure up to $20 \mathrm{Mpa}$. The hydrotreating process includes hydrodemetallization for metal removal, hydrodesulfurization for $\mathrm{S}$ removal, hydrodenitrogenation for $\mathrm{N}$ removal, and hydrodeoxygenation for oxygen removal. Hydrotreating processes usually occur in the presence of a catalyst, and the most traditional catalysts used for hydrotreatment are NiMo, $\mathrm{NiW}$, and CoMo [42]. Owing to the complexity of bio-oil's chemical composition, a series of reactions possibly occur in bio-oil upgrading, as depicted in Figure 5. The main advantages and disadvantages of each upgrading method are summarized in Table 5.

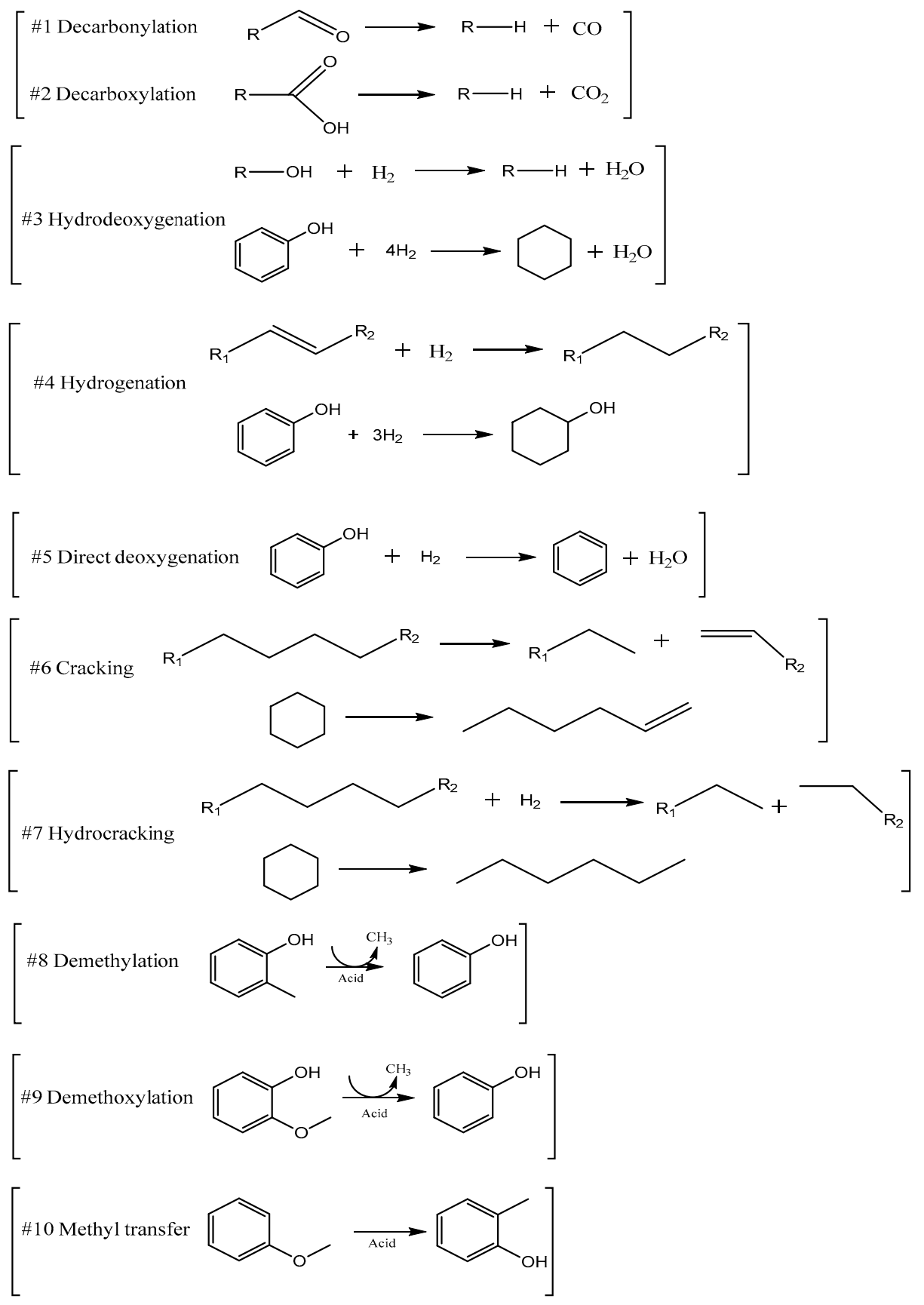

Figure 5. A comprehensive reaction network in bio-oil upgrading. Reprinted from reference [43]. 
Table 5. An overview of the advantages and disadvantages of various upgrading methods $[24,44,45]$.

\begin{tabular}{ccl}
\hline Upgrading Approach & Advantages & \multicolumn{1}{c}{ Disadvantages } \\
\hline Emulsion & Easy-operation & $\begin{array}{l}\text { High-cost of surfactant; high energy } \\
\text { consumption; cannot remove } \\
\text { unfavourable substances }\end{array}$ \\
\hline Solvent addition & Easy-operation & Cannot remove unfavourable substances \\
\hline Hydrocracking & The formation of light components & $\begin{array}{l}\text { The requirement for a high-pressure } \\
\text { resistant reactor, coke formation; catalyst } \\
\text { deactivation; high-pressure } \mathrm{H}_{2} \text { is needed }\end{array}$ \\
\hline Hydrotreatment & $\begin{array}{c}\text { Well-established treatment in oil } \\
\text { refineries; effectively removes } \\
\text { heteroatoms }\end{array}$ & $\begin{array}{l}\text { The requirement for a high-pressure } \\
\text { resistant reactor; coke formation; catalyst } \\
\text { deactivation; high-pressure } \mathrm{H}_{2} \text { is needed }\end{array}$ \\
\hline Steam reforming & $\begin{array}{c}\text { Highly energy-dense } \mathrm{H}_{2} \text { as the main } \\
\text { product }\end{array}$ & $\begin{array}{l}\text { The requirement for } \\
\text { high-temperature-resistant reactor }\end{array}$ \\
\hline Supercritical fluids & $\begin{array}{c}\text { Significantly lowers the viscosity } \\
\text { and increases HHV of bio-oil }\end{array}$ & $\begin{array}{l}\text { High-cost of the solvent; requirement for } \\
\text { high-pressure resistant reactor }\end{array}$ \\
\hline Esterification & $\begin{array}{c}\text { Easy-operation; moderate reaction } \\
\text { conditions }\end{array}$ & $\begin{array}{l}\text { Cannot remove nitrogenates and thus } \\
\text { cannot be used for algae-derived bio-oil }\end{array}$ \\
\hline
\end{tabular}

\section{Hydrodeoxygenation}

As one of the hydrotreatment approaches, HDO is highly effective in removing oxygen from bio-oil through water formation. The yield and properties of upgraded bio-oil obtained from HDO are dependent on the temperature, residence time, pressure, solvent, catalyst type, and reactor configuration. The selection of a suitable catalyst is a critical aspect of the HDO process.

\section{Catalytic Hydrodeoxygenation}

Hydrodeoxygenation HDO is an upgrading process applied to produce a high-quality oil yield with higher carbon content. The process involves removing oxygen from a hydrocarbon by applying different catalytic reactions at pressures up to 200 bar and temperatures up to $400{ }^{\circ} \mathrm{C}$ [46]. The HDO process occurs through different reactions, including the hydrogenation of $\mathrm{C}-\mathrm{O}, \mathrm{C}=\mathrm{O}$ and $\mathrm{C}=\mathrm{C}$ bonds, the dehydration of the $\mathrm{C}-\mathrm{OH}$ group, condensation and the decarbonylation of the $\mathrm{C}-\mathrm{C}$ bond cleavage using retro-aldol and the hydrogenolysis of $\mathrm{C}-\mathrm{O}-\mathrm{C}$ bonds $[47,48]$. Hydrodeoxygenation of biomass can occur through different biomass conversion techniques, which include the hydrotreating of bio-oils [49], hydropyrolysis [50], hydrogenolysis of biomass into oxygenated chemicals [51], aqueous-phase reforming of carbohydrates into fuel [52] and hydrotreating of organics acids. The main reactions that take place during the HDO involve the separation of water that exists with oil, then the oil being exposed to a dehydration reaction as a result of a condensation-polymerization reaction, followed by a decarboxylation reaction where oxygen is eliminated in the form of $\mathrm{H}_{2} \mathrm{O}$, then the oil is exposed to a hydrogenation reaction to transfer the unsaturated bonds formed during the reaction into saturated bonds, and a hydrogenolysis reaction, which breaks down the $\mathrm{C}-\mathrm{O}$ bond and liberates the oxygen in the form of $\mathrm{H}_{2} \mathrm{O}$. A hydrocracking reaction occurs to crack the high molecular weight compounds into low molecular weight compounds in the last step.

Attributed to the series of reactions, like oligomerization and polymerization, occurring between the different oxygenated functionalities [28]. 
Elkasabi et al. [53] upgraded the various bio-oil samples obtained from the fast pyrolysis of Switchgrass, Eucalyptus benthamii, and horse manure by $\mathrm{HDO}$ at $320^{\circ} \mathrm{C}$ and 145 bar for $4 \mathrm{~h}$ over a Pt, $\mathrm{Ru}$, and $\mathrm{Pd}$-based catalyst, and HDO using $\mathrm{Pt} / \mathrm{C}$ as the catalyst of switchgrass-derived bio-oil, which led to the highest oxygen reduction rate and carbon retention. The authors also reported that the bio-oil containing high syringe content greatly influenced $\mathrm{H}_{2}$ consumption. However, there are two main drawbacks to the HDO process, including the requirement for high-pressure $\mathrm{H}_{2}$ and a short catalyst lifetime caused by the coke formation [54].

Elliott and his co-worker developed a two-stage hydrodeoxygenation process for pyrolysis bio-oil $[55,56]$. The first step of the process is the catalytic hydrogenation of the thermally unstable bio-oil at a temperature of $270{ }^{\circ} \mathrm{C}$ and pressure of $136 \mathrm{~atm}$ using $\mathrm{Co}-\mathrm{Mo} / \mathrm{Al}_{2} \mathrm{O}_{3}$ or $\mathrm{Ni}-\mathrm{Mo} / \mathrm{Al}_{2} \mathrm{O}_{3}$ catalysts that were sulfides firstly in the reactor. The thermally unstable bio-oil compounds usually decompose, forming cock that directly plugs the reactors. The main hydrodeoxygenation reaction primarily occurs in the second step, which involves a catalytic hydrogenation reaction but at a higher temperature, reaching up to $400{ }^{\circ} \mathrm{C}$, and at the same pressure using the same catalyst. The main findings of the process are the production of $0.4 \mathrm{~L}$ of treated oil for every $1 \mathrm{~L}$ of bio-oil and converting $20-30 \%$ of the $\mathrm{C}$ existing in the bio-oil into gas-phase carbon, which decreased the oil yield.

The two-stage hydrodeoxygenation process was also performed by Furimsky, (2000) for the conversion of biomass pyrolysis oil into high-quality oil [48]. The first stage involves removing the unstable oxygenated compounds to produce a stable crude at a low temperature below $300^{\circ} \mathrm{C}$ with the sulfide NiMo or CoMo catalyst. The second stage of the process is mainly performed to convert the low HDO reactivity compounds, such as furans and phenols, into deoxygenated compounds at $350{ }^{\circ} \mathrm{C}$ and $13.8 \mathrm{Mpa}$. The main disadvantage of the process is the short lifetime of the catalyst due to the support breakdown. Ly et al., (2019) [57] hydrotreated bio-oil obtained from the fast pyrolysis of Saccharina japonica in a fluidized bed reactor at $350^{\circ} \mathrm{C}$ and $3-15$ bar of $\mathrm{H}_{2}$ over HZSM-5, $\mathrm{Co} / \gamma-\mathrm{Al}_{2} \mathrm{O}_{3}$, $\mathrm{CoP} / \gamma-\mathrm{Al}_{2} \mathrm{O}_{3}, \mathrm{CoMoP} / \gamma-\mathrm{Al}_{2} \mathrm{O}_{3}, \mathrm{Fe} / \gamma-\mathrm{Al}_{2} \mathrm{O}_{3}$, and $\mathrm{Fe}_{2} \mathrm{P} / \gamma-\mathrm{Al}_{2} \mathrm{O}_{3}$. The oxygen content in the bio-oil was removed through the formation of water, $\mathrm{CO}$, and $\mathrm{CO}_{2}$.

Meanwhile, an increase in the kerosene-diesel fraction of bio-oil was found. Schmitt et al., (2018) [58] performed catalytic HDO experiments on beech wood-derived bio-oil at $175-325^{\circ} \mathrm{C}$ and 80-100 bar of $\mathrm{H}_{2}$, and the results indicated that around $42 \%$ of oxygen content in the crude bio-oil was eliminated at $325{ }^{\circ} \mathrm{C}$ and 80 bar and the ketones that cause the chemical instability of bio-oil were observed to be removed entirely. Delmon and his co-workers have studied the hydrodeoxygenation of a mixture of 4-methyl acetophenone, ethyl decanoate, and guaiacol as a model compound [59-63], Figure 6. The ketone group is highly reactive toward the HDO process; therefore, it is easily hydrogenated into a methylene group at a low temperature of $200^{\circ} \mathrm{C}$ [61]. The hydrodeoxygenation of the carboxylic and guaiacol groups requires a temperature higher than $300^{\circ} \mathrm{C}$ to be converted into deoxygenated compounds because of the lower reactivity of the two groups than the ketonic group. It was noticed that there is a decarboxylation pathway parallel to the hydrogenation of the carboxylic acid at comparable rates [61]. Guaiacol was converted into catechol then phenol, and the catalyst was deactivated during the high-temperature reactions due to coke formation. Increasing the acidity of the catalyst support does not affect the hydrogenation of 4-methyl acetophenone but raises the rate of decarboxylation and coke formation from the guaiacol group. It was found that the presence of water strongly affects the catalyst activity and decreases it by one-third of its initial activity. 
<smiles>C=Cc1ccc(C(C)C)cc1</smiles>

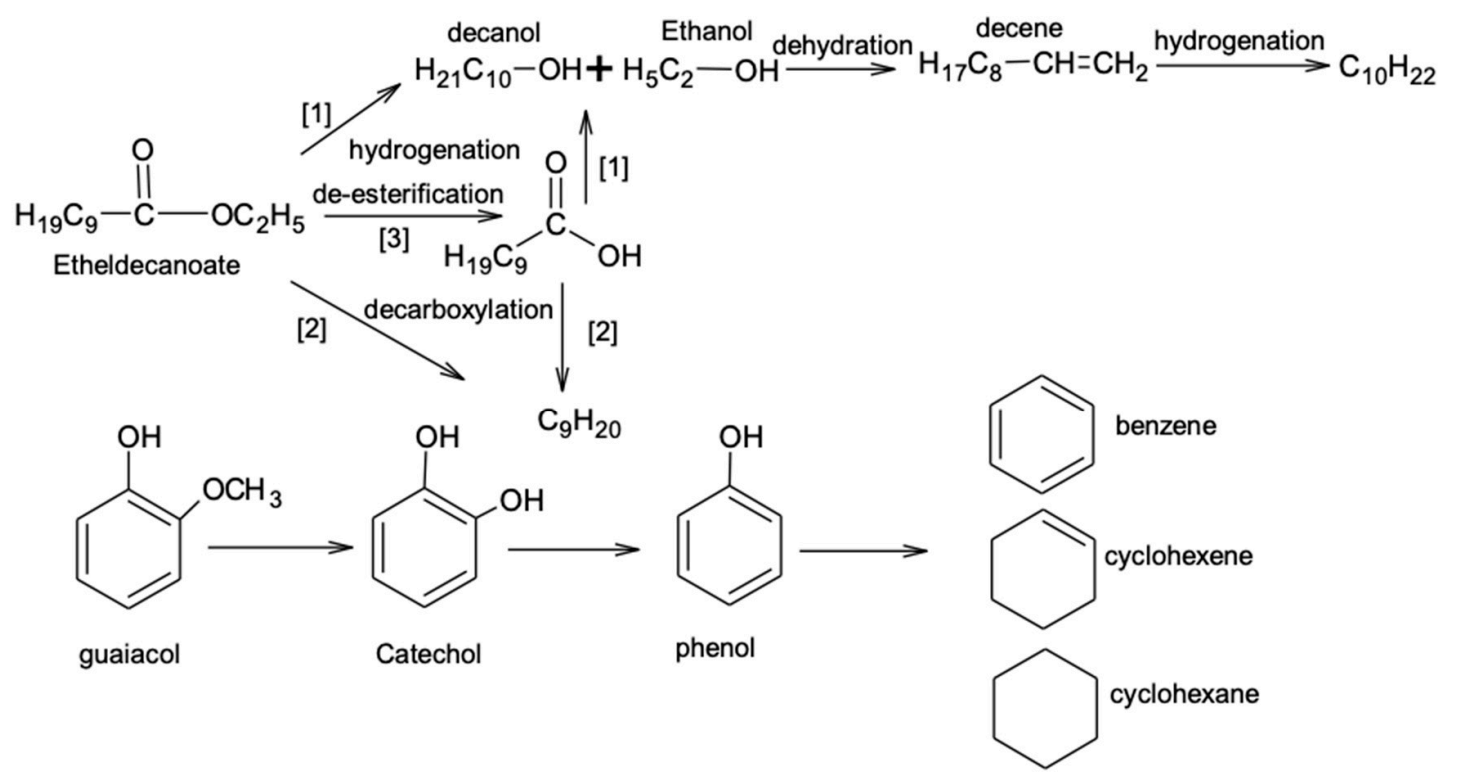

Figure 6. Hydrodeoxygenation of 4-methyl acetophenone, ethyl decanoate, and guaiacol. Reproduced from reference [63].

\section{HDO Catalysts}

Until this point, a great effort has been made to study the formation of different catalysts using noble and non-noble metals for the HDO process. Recently, a novel, multifunctional red mud-supported nickel (Ni/red mud) was synthesized for the hydrodeoxygenation of aqueous-phase, pinyon-juniper, biomass chips. The process was performed using a $30 \mathrm{wt} . \%$ of the Ni/red mud catalyst at a temperature of $350{ }^{\circ} \mathrm{C}$. The process's main findings are the production of $47.8 \mathrm{wt} . \%$ of the organic liquid yield with an oxygen content of $1.14 \mathrm{wt} . \%$. The organic liquid yield is mainly composed of aliphatics, aromatics, and alkylated aromatic hydrocarbons with small oxygen content. In comparison, the commercial $\mathrm{Ni} / \mathrm{SiO}_{2}-\mathrm{Al}_{2} \mathrm{O}_{3}$ catalyst was used as well in the $\mathrm{HDO}$ process. The $65 \mathrm{wt} . \%$ of the catalyst was gasified in the feed's organic phase and did not produce liquid hydrocarbons [64].

Different groups of catalysts have been investigated for the HDO of fast pyrolysis bio-oil, which can be classified into sulphides, transition metals, phosphides, and other catalysts (carbides and nitrides) [43].

\subsection{Sulphide Catalysts}

$\mathrm{CoMoS}_{2}$ and $\mathrm{NiMoS}_{2}$ have been widely applied not only in conventional hydrotreatments but also in HDO reactions. For $\mathrm{CoMoS}_{2}$ and $\mathrm{NiMoS}_{2}, \mathrm{Co}$ or Ni acts as the promoter and donates an electron to the Mo atom, thereby weakening the bond between Mo and $\mathrm{S}$ and creating an $\mathrm{S}$ vacancy site is reported to be an active site during the HDO process [40]. During the upgrading treatment of petroleum crude oil, $\mathrm{CoMoS}_{2}$ and $\mathrm{NiMoS}_{2}$ can be maintained in the form of sulfide due to the presence of $\mathrm{H}_{2}$ and $\mathrm{H}_{2} \mathrm{~S}$ in the reactor. These components are generally directly produced from the thiols in the petroleum oil. On the contrary, due to a limited or zero sulfur content in the biomass, the sulfide in the form of $\mathrm{CoMoS}_{2}$ and $\mathrm{NiMoS}_{2}$ cannot be maintained, and they are often transformed into the corresponding oxide forms if no sulfur source is added to the system. However, the addition of an 
extra sulfur source could result in the catalyst being poisoned in the post-processing and $\mathrm{SO}_{x}$ emission upon combustion [65]. Zhang et al. [66] reported that a 90\% oxygen removal efficiency from the bio-oil was achieved using a dispersed unsupported $\mathrm{MoS}_{2}$ catalyst, and the coke formation was in the range of 0.8/100 g of bio-oil to 1.8/100 g of bio-oil. Kanhoinnon et al. [33] high catalytic activity of molybdenum sulphide in the catalytic HDO of furan and 2-methyl furan at $400{ }^{\circ} \mathrm{C}$ and 70 bar $\mathrm{H}_{2}$. The reaction mechanism for the HDO of 4-methyl phenol over $\mathrm{MoS}_{2}$ was proposed by Wang et al. [67], as shown in Figure 7. Table 6 presents the HDO of various feedstocks over sulphide catalysts.

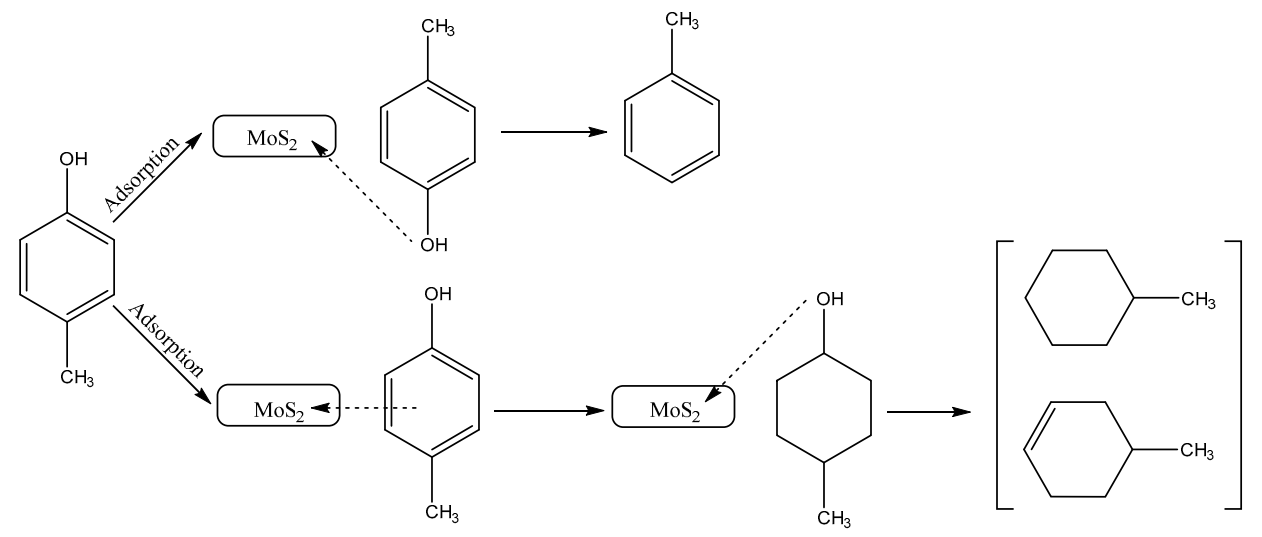

Figure 7. The reaction mechanism for the HDO of 4-methyl phenol over $\mathrm{MoS}_{2}$. Reprinted from reference [67].

Table 6. HDO of different compounds over sulphied catalyst.

\begin{tabular}{cccc}
\hline Catalyst & Oxygenate Compound & Deoxygenated Compound & Ref. \\
\hline $\mathrm{NiMoS}_{\mathrm{MoS}}$ & Phenol & Guaiacol & Cyclohexane, Benzene, Cyclohexene \\
$\mathrm{MoS}$ & Phenol & Phenol, cyclohexane, benzene, methyl cyclopentane & [68] \\
$\mathrm{NiMoS}$ & 2,3-dihudro benzofuran & Benzene, cyclohexene, cyclohexane \\
$\mathrm{NiMo}, \mathrm{CoMo}$ & Waste cooking oils & 2-Ethylphenol, ethyl cyclohexane & [70] \\
$\mathrm{CoMoWS} / \mathrm{SBA}-15$ & Anisole & Phenol & n-paraffins, isoparaffins, a small amount of olefins \\
$\mathrm{CoMoS} / \mathrm{MgO}$ & Phenol & Phenol, cresol, xylenol & [72] \\
$\mathrm{CoMoS}$ & 2-Cyclohexylphenol, cyclohexylbenzene, cyclohexanol \\
$\mathrm{Ni}-\mathrm{Mo}$ & 2,3-dihydro benzofuran & Ethyl benzene, ethyl-cyclohexane, ethylcyclohexene, methylcyclohexane, and cyclohexane & [73] \\
$\mathrm{ReS}_{2} / \mathrm{AC}$ & Guaiacol & Phenol, catechol & [75] \\
\hline
\end{tabular}

\subsection{Oxide Catalysts}

It had been reported previously in the literature that oxide catalysts, such as $\mathrm{Mo}, \mathrm{Ni}, \mathrm{W}$, and $\mathrm{V}$, exhibit significant catalytic activity in the HDO reaction. Based on the basic mechanism of oxide catalysts, a low $\mathrm{H}_{2}$ pressure is needed to limit the transformation of active species into inactive species; however, a high pressure of $\mathrm{H}_{2}$ is a necessity to avoid coke formation during the HDO process. Generally, the catalytic activity of oxides in the HDO mainly depends on the acidic sites. At the initial chemisorption stage, the Lewis acidity is the key factor and the oxygen lone pair of the oxygenated compounds can be chemisorbed, and the availability of acidic sites on the oxide catalyst is affected by the Brønsted acidity [43]. Previously, Prasomsri et al. [76] found that the use of $\mathrm{MoO}_{3}$ effectively deoxygenated the linear and cyclic ketones, phenolics, and cyclic ethers at low $\mathrm{H}_{2}$ pressure of $\leq 1$ bar.

\subsection{Transition Metal Catalysts}

Transition metal catalysts, including $\mathrm{Ni}, \mathrm{Pt}, \mathrm{Pd}, \mathrm{Ru}$, and $\mathrm{Rh}$, promote the $\mathrm{HDO}$ and hydrogenation reactions, and their reaction rates are proportional to $\mathrm{H}_{2}$ pressure. Compared to sulfide catalysts, there is no requirement for the additional sulfur source to maintain the active form. The main drawback for the transition metal catalysts is related to their high sensitivity to sulfur; hence, it is necessary to remove sulfur-containing compounds from bio-oil before HDO treatment [43]. In a previous study conducted by [77], the catalytic activity in the HDO of guaiacol in hexadecane at $100{ }^{\circ} \mathrm{C}$ for 80 bar 
of $\mathrm{H}_{2}$ was as follows: $\mathrm{Rh} / \mathrm{ZrO}_{2}>\mathrm{CoMoS}_{2} / \mathrm{Al}_{2} \mathrm{O}_{3}>\mathrm{Pd} / \mathrm{ZrO}_{2}>\mathrm{Pt} / \mathrm{ZrO}_{2}$. Until now, though, the basic mechanism for transition metal in the HDO reaction is still not clear. It is accepted that the metal plays a role in the hydrogen donation; however, there is no conclusion on the mechanism for the activation of oxygenates.

Phosphide, Carbide, and Nitride Catalysts

Phosphide catalysts have been broadly studied in hydrotreatment for the petroleum industry and have thus drawn attention recently in the HDO reaction of bio-oil, which accounts for the presence of acidic sites and $\mathrm{H}_{2}$-activating sites [78]. Moreover, phosphide catalysts are characterized by the low activation energy required and highly active [66]. Mendes et al. [79] prepared a nickel-phosphide supported on a carbon-covered alumina catalyst $\left(\mathrm{Ni}_{2} \mathrm{P} / \mathrm{CCA}\right)$ to upgrade bio-oil by conducting the HDO process at $250^{\circ} \mathrm{C}$ and 75 bar of $\mathrm{H}_{2}$ in a batch reactor. The results indicated that similar catalytic activity was provided by $\mathrm{Ni}_{2} \mathrm{P} / \mathrm{CCA}$ when compared to a commercially-available catalyst $(\mathrm{Ru} / \mathrm{C})$. Gutierrez-Rubio et al. [80] investigated the catalytic HDO reaction of the mixture of guaiacol and acetic acid over $\mathrm{Ni}_{2} \mathrm{P} / \mathrm{ZSM}-5$ at $260-300^{\circ} \mathrm{C}$ and $40-100$ bar of $\mathrm{H}_{2}$. The results showed that low deoxygenation efficiency resulted from the use of $\mathrm{Ni}_{2} \mathrm{P} / \mathrm{ZSM}-5$ as the catalyst since the presence of acetic acid could partially block the active sites of the catalyst. Thus, it can be speculated that the removal of carboxylic acid from bio-oil before the HDO reaction might be useful to ensure a high catalytic activity.

Except for phosphide catalysts, as discussed above, carbides and nitrides have recently attracted a great deal of attention, owing to their low-cost and comparable properties to common HDO catalysts. Previously, Lopez et al. [81] used a molybdenum carbide catalyst in the HDO process to upgrade acacia wood or empty fruit bunches-derived bio-oil at $350{ }^{\circ} \mathrm{C}$ and 50 bar of $\mathrm{H}_{2}$ for $4 \mathrm{~h}$, and it was observed that the oxygen content of bio-oil was greatly reduced and thus improved the HHV of bio-oil from $29.1 \mathrm{MJ} / \mathrm{kg}$ to $36.9 \mathrm{MJ} / \mathrm{kg}$ due to the formation of the hexagonal $\beta-\mathrm{Mo}_{2} \mathrm{C}$ phase that demonstrates a strong ability for the deoxygenation. In the catalyst recycling studies, the high catalytic activity of $\mathrm{NiMoS}_{2}$ was maintained after being recycled 5 times. Vasilevich et al. [1]. carried out the catalytic HDO experiments for guaiacol over $\mathrm{Mo}_{2} \mathrm{C} / \mathrm{SBA}-15$ at $320^{\circ} \mathrm{C}$ and 40 bar of $\mathrm{H}_{2}$ for $180 \mathrm{~min}$ in a batch reactor, and a $70-73 \%$ conversion of guaiacol was attained. Even though few studies so far have investigated the influence of nitride catalysts on the HDO, it is obvious that they are more favorable than water-sensitive carbide catalysts. The presence of water, however, is normal during the HDO treatment [43]. Thus, future work must be focused on the effects of nitride catalysts on the bio-oil HDO in terms of product properties, reaction mechanism, kinetics, and deactivation.

Despite the fact that phosphide, nitride, and carbide catalysts demonstrate effective HDO efficiency for the bio-oil, they remain at the initial development stage and thus cannot be replaced with the commercial sulfide catalysts in terms of industrial applications.

\section{HDO of Different Biomass-Derived Oxygenates}

\subsection{HDO of Lignin-Derived Oxygenates}

\subsubsection{Phenol and Alkylated Phenol}

Phenolic monomers mainly consisting of phenols, guaiacols, and syringols as the model compounds are the simplest product obtained from lignin degradation. Phenol and alkylated phenols (such as cresol and 2-ethylphenol) are the basic lignin-derived phenolic monomers. The cleavage of the $\mathrm{C}-\mathrm{OH}$ bond is the key element for the HDO process. As shown in Figure 8 there are two common reaction routes to produce cycloalkanes and arenes: (i) hydrogenation of the aromatic ring and then alcohols undergo deoxygenation to generate cycloalkanes; and (ii) the direct deoxygenation into arenes through the $\mathrm{C}-\mathrm{OH}$ bond breakage [82]. 

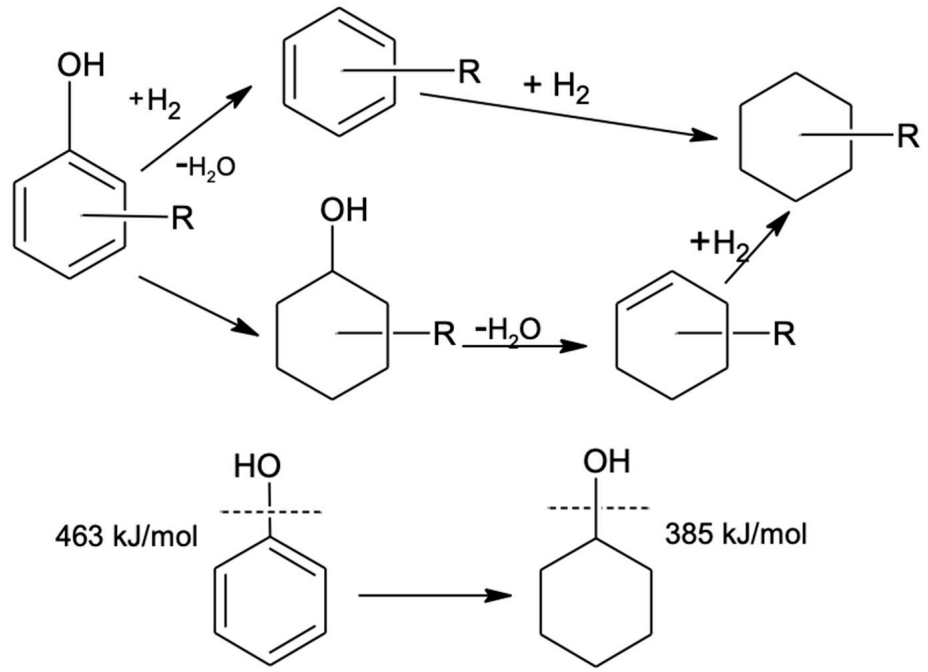

Figure 8. The reaction pathway of phenols. Reproduced from reference [82].

\subsubsection{Guaiacol}

The conversion of guaiacol to phenol undergoes a series of reactions, such as deoxygenation, demethoxylation, and demethylation as shown in Figure 9. During the process of demethylation and demethoxylation, guaiacol is converted to form catechol and phenol, respectively. On the other hand, catechol is further converted to phenol and its derivatives methylcatechol via hydrogenation. Following this, these intermediates further deoxygenate to form benzene, cyclohexane, methylcyclohexane, and other hydrocarbons [83].<smiles>Cc1ccc(O[C+]c2cc(C)c(O)c(O)c2)c(O)c1</smiles>

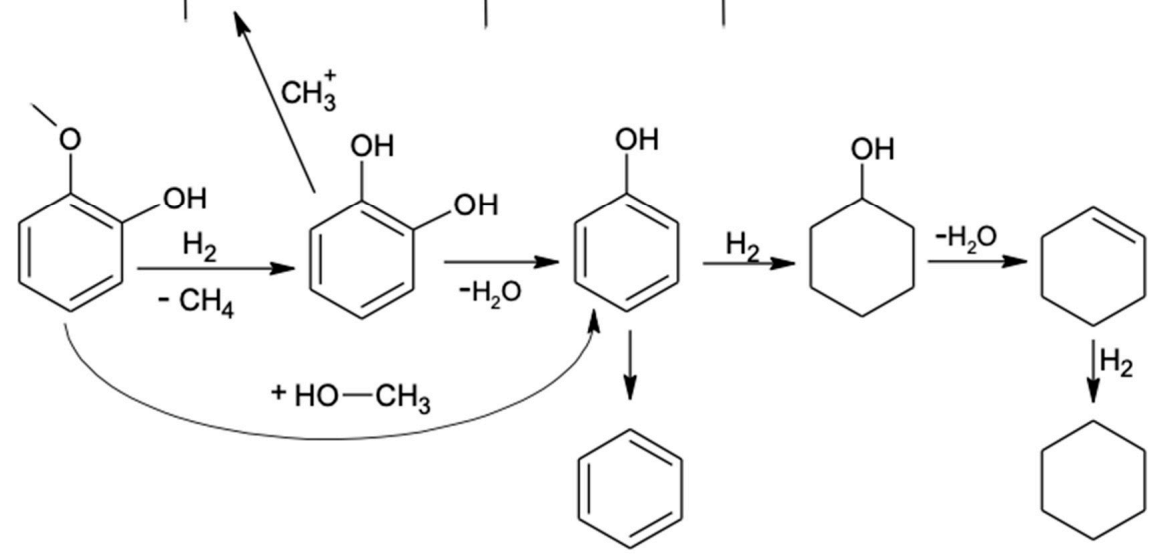

Figure 9. The reaction mechanism for the HDO of guaiacol. Reproduced from reference [83]. 


\subsubsection{Phenolic Dimers}

Phenolic dimers share a similar chemical structure to that of lignin. The most important reaction in the HDO of phenolic dimers, as presented in Figure 10, is the breakage of the ether linkage. $\beta-\mathrm{O}-4, \alpha-\mathrm{O}-4$ and $4-\mathrm{O}-5$ are the typical linkages in the lignin molecular, as presented in Figure 10. After the cleavage of ether bonds, phenolic monomers are created, and they follow the same reaction as discussed above.
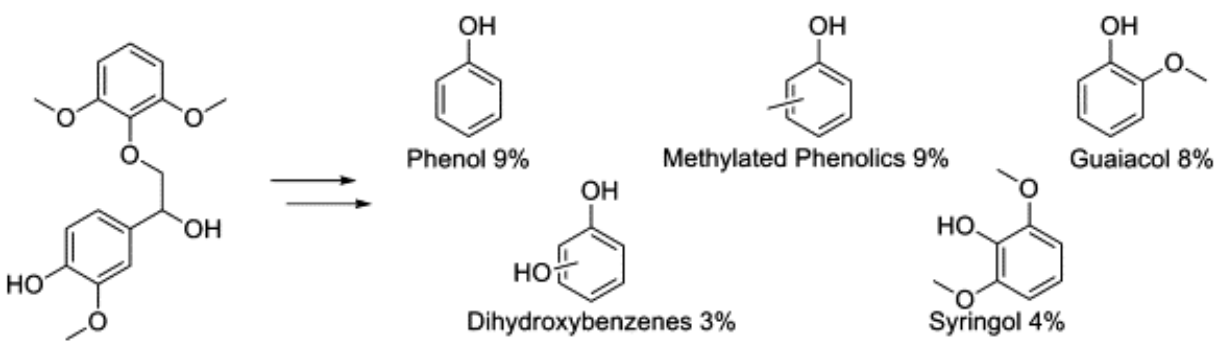

Figure 10. The reaction mechanism for the HDO of $\beta-\mathrm{O}-4$ dimers. Reprinted from reference [84].

\subsection{HDO of Carbohydrates-Derived Oxygenates}

In general, lower deoxygenation temperatures are needed for the carbohydrates-derived oxygenates, such as organic acid and ketone, compared to lignin-derived oxygenates, and the same trend can be observed for the activation energy.

\subsubsection{Levulinic Acid}

Levulinic acid is one of the most reactive biomass compounds that can be produced from lignocellulosic waste at a low cost [85]. Due to the high reactivity of the functional groups existing in the composition of the Levulinic acid, the acid can be converted into an upgraded high-quality biofuel [86].

The main reaction pathways for the HDO of levulinic acid, as shown in Figure 11, include: (1) the HDO of levulinic acid into $\alpha$ - or $\beta$-angelica lactone via dehydrative cyclization and then hydrogenated into $\gamma$-valerolactone, (2) the hydrogenation of levulinic acid to form 4-hydroxypentanoic acid, followed by the dehydrative cyclisation into $\gamma$-valerolactone, (3) the direct decarboxylation of levulinic acid to produce 2-butanone and (4) the $\mathrm{C}-\mathrm{C}$ coupling reaction by aldol addition [87].

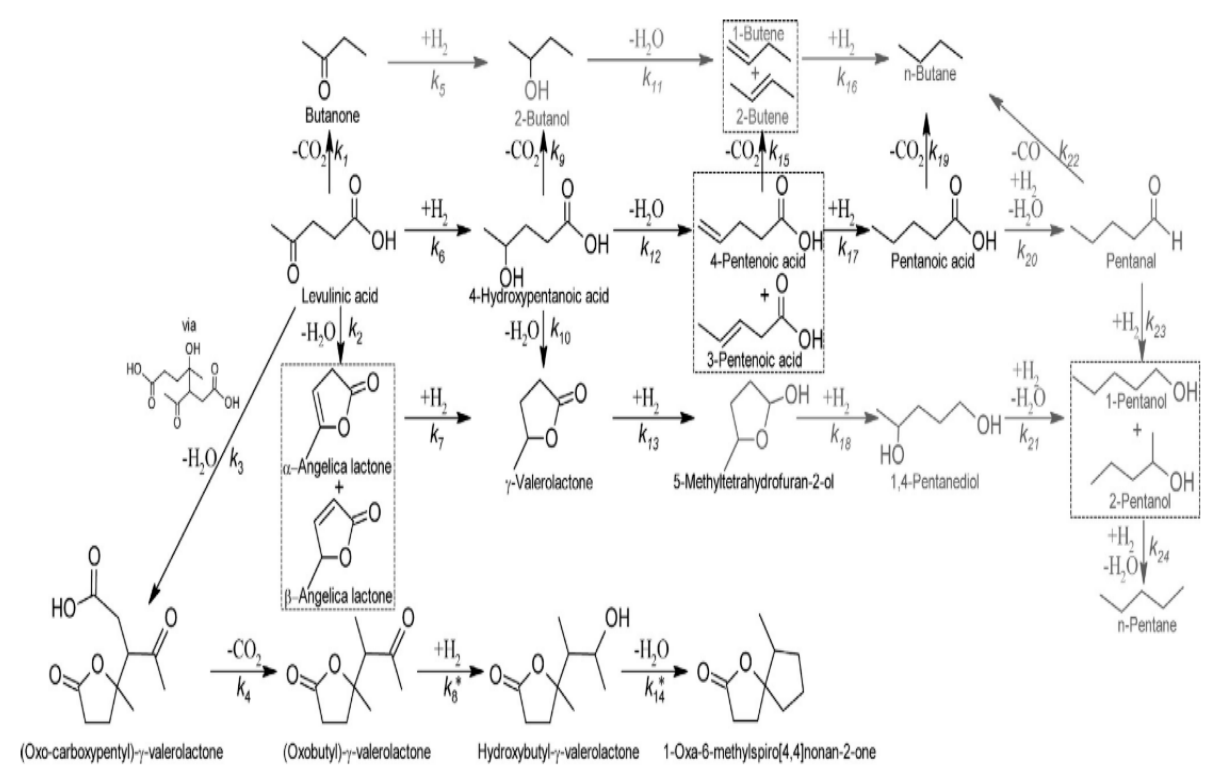

Figure 11. Reaction mechanism for the HDO of levulinic acid. Reprinted from reference [87]. 


\subsubsection{Acrylic Acid}

As illustrated in Figure 12, initially, acrylic acid adsorbs parallel to the surface, followed by deprotonation to form a propenoate species and dehydration to produce $\mathrm{H}_{2} \mathrm{C}=\mathrm{CH}-\mathrm{CO}$ on the $\mathrm{Mo}_{2} \mathrm{C} / \mathrm{Al}_{2} \mathrm{O}_{3}$ catalyst surface. Subsequently, hydrogen attacks the carboxylic group of $\mathrm{H}_{2} \mathrm{C}=\mathrm{CH}-\mathrm{CO}$ and thus results in the formation of 2-propenal, which can be further converted into propane by hydrogenation [88].

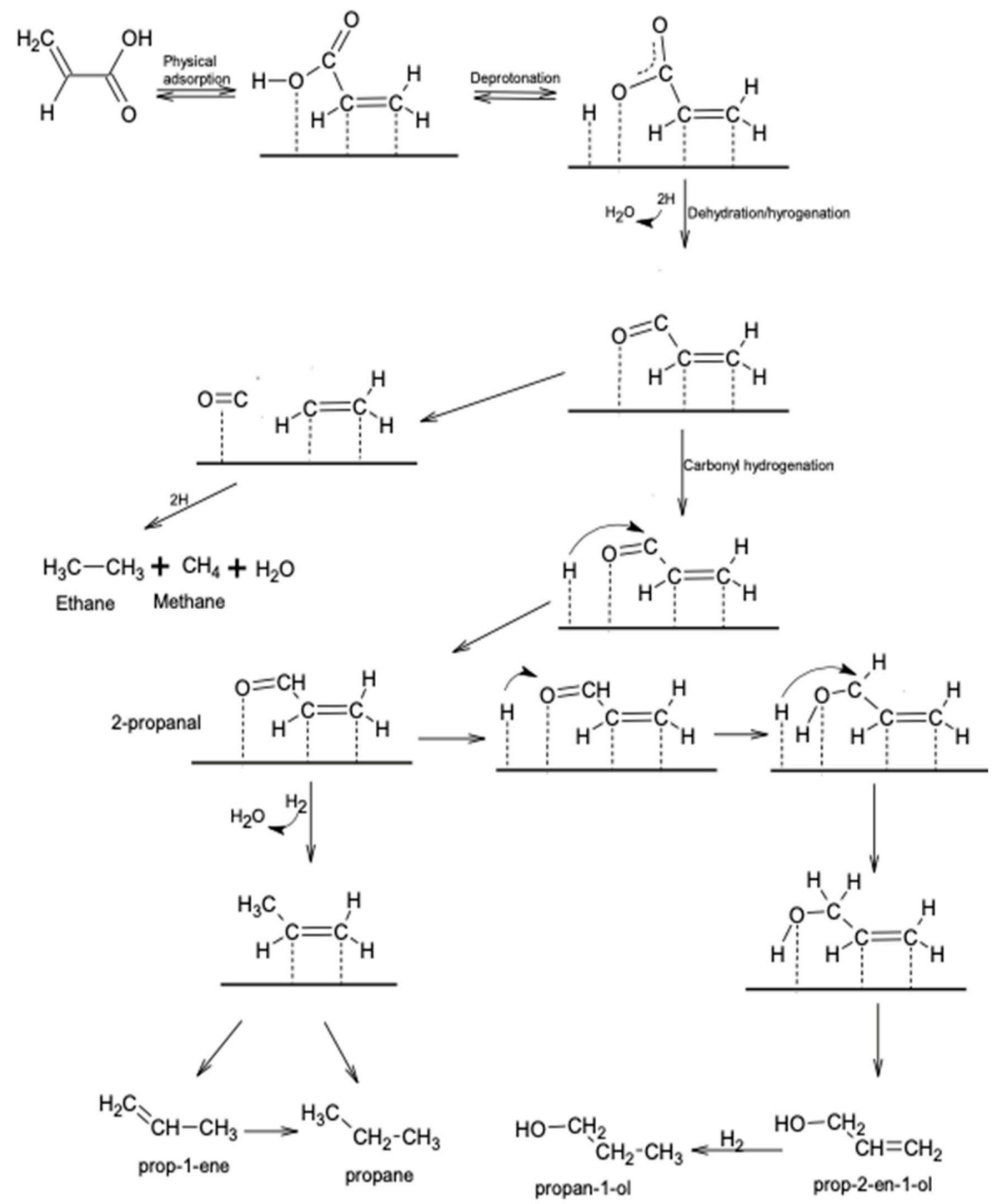

Figure 12. Reaction mechanism for the HDO of acrylic acid. Reproduced from reference [88].

\subsubsection{Furfurals}

A new pathway for furfural HDO over a Cu-based catalyst was proposed by Zheng et al. [89], Figure 13. In the proposed pathway, the furfural is first exposed to hydrogenation to produce furfuryl alcohol and C-C cleavage yielding furan. With successive hydrogenations of furan, it has two pathways: the first pathway produces n-butanal that can give n-butanol; the second pathway is the production of tetrahydrofuran. There are three pathways for converting furfuryl alcohol: The first pathway can occur through the $\mathrm{C}-\mathrm{C}$ bond cleavage between the methyl alcohol side and the furan groups, which gives rise to furan formation. The second pathway is the hydrogenation of furfuryl alcohol into tetrahydrofurfuryl alcohol. Tetrahydrofurfuryl alcohol can produce $\delta$-valerolactone. Through the $\mathrm{C}-\mathrm{O}$ bond cleavage or tetrahydrofuran through $\mathrm{C}-\mathrm{C}$ cleavage, 2-methyl furan can be produced via the $\mathrm{C}-\mathrm{O}$ 
bond cleavage. Different products, such as 1-pentanol, 2-pentanone, and 2-methyl tetrahydrofuran, can be produced from 3-methyl furan through the $\mathrm{C}-\mathrm{O}$ bond cleavage [89].

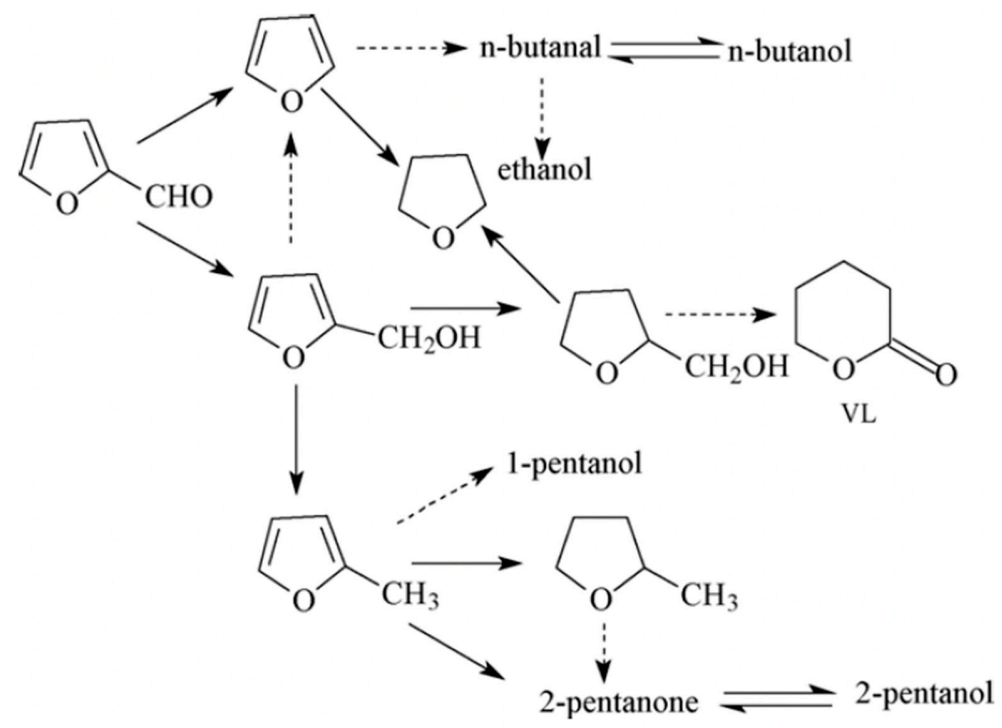

Figure 13. HDO pathways of furfural. Reprinted from reference [89].

Other several feedstocks that were exposed to a treatment process for oxygen removal using the HDO process are shown in Table 7.

Table 7. HDO of different feedstocks and model compounds, including the applied catalyst.

\begin{tabular}{|c|c|c|c|}
\hline Feedstock & Catalyst & Conclusions & Reference \\
\hline $\begin{array}{l}\text { Eugenol + Light fraction } \\
\text { of bio-oil }\end{array}$ & Ni-based & $\begin{array}{l}\text { Highest product selectivity of propyl-cyclohexane was } 67.9 \% \text { and all } \\
\text { eugenol can be converted } \\
\text { Al-SBA-15 was mixed with ZSM- } 5 \text { as the support to enhance the } \\
\text { catalytic activity } \\
\text { The presence of acetic acid and furfural affected the HDO of eugenol }\end{array}$ & [90] \\
\hline Fast pyrolysis bio-oil & $\mathrm{MoS}_{2}$ & $\begin{array}{l}90 \% \text { of O from the bio-oil was removed } \\
\text { The formation of coke was not obvious }\end{array}$ & [66] \\
\hline Fast pyrolysis bio-oil & $\beta-\mathrm{Mo}_{2} \mathrm{C}$ & $\begin{array}{l}\text { The HHV of upgraded bio-oil was } 41.1 \mathrm{MJ} / \mathrm{kg} \text {; Catalyst was highly } \\
\text { stable upon recycling and it was easy to recycle }\end{array}$ & [81] \\
\hline Cyclohexanone & Co-based & $\begin{array}{l}\text { Catalyst had high catalytic activity and selectivity for cyclohexanone to } \\
\text { produce cyclohexane, cyclohexene, benzene, and cyclohexylbenzene } \\
100 \% \text { of hydrocarbon selectivity and } 89 \% \text { of cyclohexanone conversion } \\
\text { were obtained at } 400{ }^{\circ} \mathrm{C} \text { and } 15 \text { bar of } \mathrm{H}_{2}\end{array}$ & [94] \\
\hline Cyclohexanone & NiMo-based & $\begin{array}{l}\mathrm{C} 6, \mathrm{C} 7, \mathrm{C} 12 \text { cyclic, aromatic, and bicyclics were the main products; } 87 \% \\
\text { of cyclohexanone conversion was obtained at } 400{ }^{\circ} \mathrm{C} \text { and } 8 \text { bar of } \mathrm{H}_{2}\end{array}$ & [95] \\
\hline Fast pyrolysis bio-oil & $\begin{array}{l}\mathrm{Pt} \text { and } \mathrm{MoO}_{3} \text {-based } \\
\text { and Mo-based } \\
\text { industrial catalyst }\end{array}$ & $\begin{array}{l}\text { All catalysts reduced O content of bio-oil to } 7-12 \mathrm{wt} . \% \text {; Pt catalyst } \\
\text { showed better performance to lower acidic value; more coke was } \\
\text { formed using Mo-based industrial catalyst }\end{array}$ & [96] \\
\hline
\end{tabular}

Although HDO is highly effective for removing oxygenates from bio-oil, one of the main challenges regarding this technology is the demand for high-pressure $\mathrm{H}_{2}$. Hence, it poses safety concerns and 
involves high costs [25]. In addition, the formation of coke, which then leads to shortening the lifetime of the catalyst, is another challenge facing the catalytic HDO that must be solved prior to its industrial-scale application.

\section{The Issue of Catalytic Deactivation in an Application and How It Can Be Solved}

\subsection{Coke Formation}

One of the problems faced by the HDO reaction is the generally very low yield of upgraded bio-oil, which is caused by the formation of char, coke, and tar. The occurrence of coke becomes severe in the case of a fixed-bed reactor where coke formation can lead to the shut-down of the reactor. A possible solution to avoid coke formation in the HDO process is to co-feed bio-oil with a hydrogen donor solvent, like methanol, tetralin, and decalin. The hydrogen donor solvents can not only promote the cracking and hydrogenation reaction but are also capable of diluting lignin and thus preventing the polymerization that forms coke at a high reaction temperature [98]. Patil et al. [83] applied tetralin as the hydrogen donor solvent in the HDO reaction of guaiacol (a model compound of lignin) and the upgrading treatment was conducted at $330{ }^{\circ} \mathrm{C}$ for $15-600 \mathrm{~min}$ and $30 \mathrm{bar}$ of $\mathrm{H}_{2}$. It was observed that a $100 \%$ conversion of guaiacol was achieved for $600 \mathrm{~min}$, accompanied by a yield of $45.3 \%$ phenol and $11.1 \%$ cyclohexane.

Coke formation is dependent on the acidity of the catalyst and the type of feedstock. In general, a higher acidic catalyst tends to promote coke formation; however, the acidity is a key element ensuring the catalytic activity. In addition, the formation of coke often occurs when using unsaturated hydrocarbons (e.g., alkenes and aromatics) as the feedstock, which could be resulting from the interaction between $\mathrm{C}=\mathrm{C}$ bonds/aromatic rings with the active sites of the catalyst. Oxygenates containing $>2$ oxygen atoms are another feedstock that have a strong tendency towards coke formation, due to the promoted polymerization reaction [99].

As suggested by Cheng et al. [99], there are several solutions to deter coke formation during HDO treatment, including (i) the use of a low acidity but high stability catalyst support, such as activated carbon and silica; (ii) carrying out HDO at moderate reaction conditions, like a relatively lower reaction condition and a higher pressure of $\mathrm{H}_{2}$; (iii) a two-stage $\mathrm{HDO}$ process; and (iv) co-processing of bio-oil and hydrogen donor solvent (e.g., methanol, ethanol, acetone, and tetralin) in the HDO reaction.

\subsection{Catalyst Deactivation}

Catalyst deactivation and its short lifetime are the bottleneck for the industrialization of the bio-oil HDO process. The primary causes of the catalyst deactivation include the following: (i) the presence of water; (ii) sintering of the active sites; (iii) poisoning by nitrogen, sulfur and chlorine; (iv) metal deposition, and (v) coke formation. Among them, the formation of coke and water exposure are the most significant factors causing the deactivation of the catalyst [100].

Cordero-Lanzac et al. [101] explored the underlying mechanism for the catalytic HDO of bio-oil obtained from the fast pyrolysis of black poplar sawdust at $400-450{ }^{\circ} \mathrm{C}$ and 65 bar of $\mathrm{H}_{2}$ over $\mathrm{Pt}-\mathrm{Pd} / \mathrm{C}$ and $\mathrm{Pt}-\mathrm{Pd} / \mathrm{Al}_{2} \mathrm{O}_{3}$. The authors stated that there were two main reaction pathways appearing in the coke formation: (i) at $400{ }^{\circ} \mathrm{C}$, the presence of unstable alkyl phenol and alkylmethoxy phenols resulted in the decomposition of thermal lignin on the external surface and mesopores of the catalyst, thereby affecting the catalytic activity and possibly causing reactor blockage; and (ii) as the temperature increased until $450{ }^{\circ} \mathrm{C}$, alkyl phenol and alkylmethoxy phenols converted into aromatics and the deposition rate of aromatic coke by condensation increased, which was further promoted by the acidic sites and high reaction temperatures. Based on these results, a possible reaction scheme for coke formation during the HDO of bio-oil was developed and illustrated in Figure 14. 


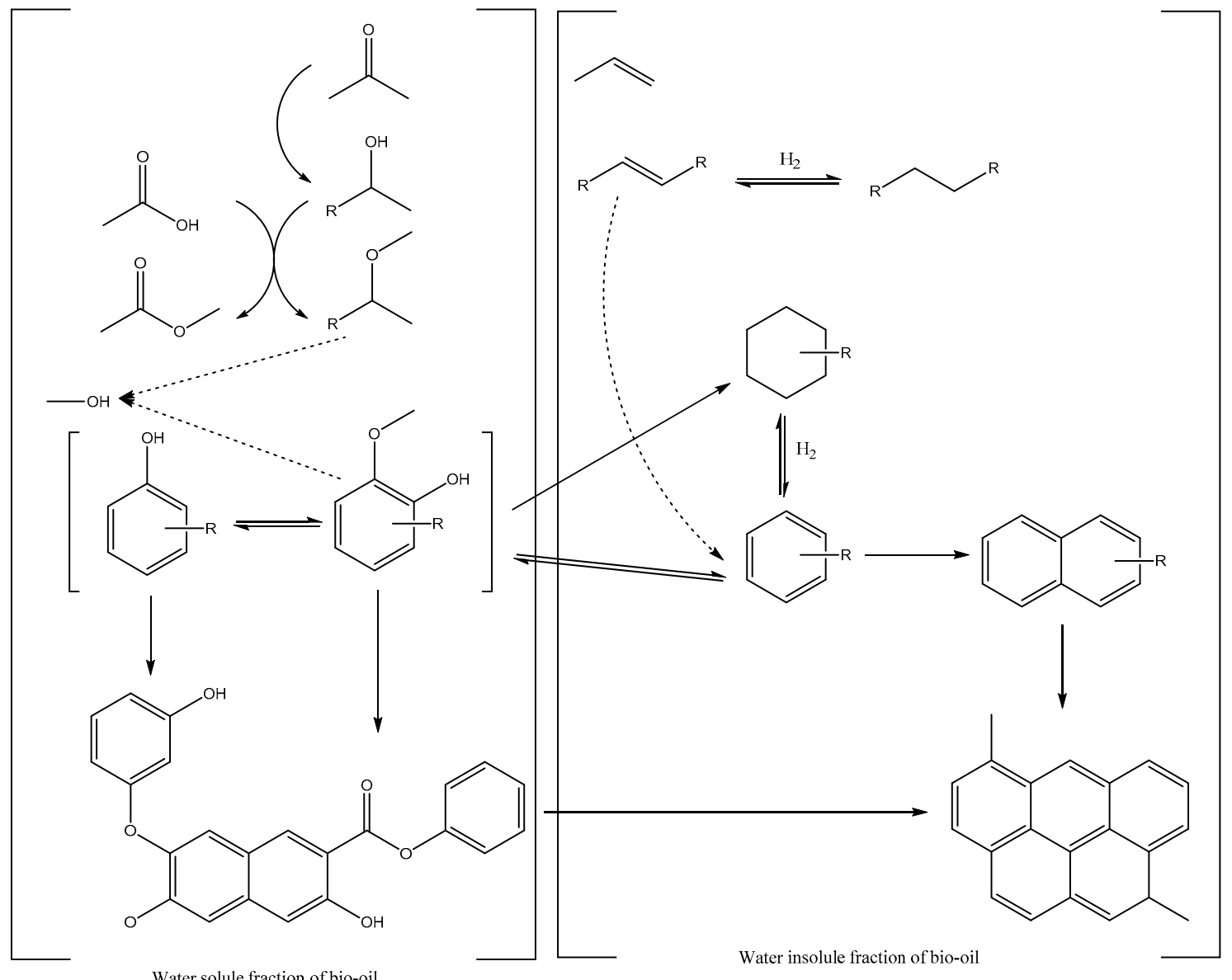

Figure 14. A reaction scheme for the HDO of bio-oil. Reprinted from reference [101].

\section{Techno-Economic Analysis of HDO}

In recent years, several researchers have performed the techno-economic analysis for the bio-oil upgrading by HDO reaction. Bagnato and Sanna [102] reported that the highest economic potential was estimated to be $\$ 38,234 \mathrm{MM} / \mathrm{yr}$ based on the capacity for upgrading bio-oil of $10 \mathrm{Mt} / \mathrm{yr}$, which was accompanied by a return on investment and pay-off time of $69.18 \%$ and 2.48 years, respectively. Carrasco et al. [103] obtained a minimum fuel selling price of $\$ 1.27$ per liter from the pyrolysis of woody biomass and $\mathrm{HDO}$ of bio-oil and the simultaneously produced $\mathrm{H}_{2}$ in a 2000 ton/day plant. They found that the high CAPEX, feedstock cost and short catalyst lifetime were the major economic concerns.

\section{Applying the Microwave in the Hydrodeoxygenation Process}

\subsection{Microwave Heating}

Electromagnetic radiation behaves like photons carrying radiated energy and waves moving at the speed of light. Electromagnetic waves are comprised of an alternating electric field orthogonal to an alternating magnetic field.

Due to the conversion of electromagnetic energy to heat taking place within the entire volume of the target material, respecting the penetration limits of the applied waves and the material, microwave heating is defined as a volumetric energy conversion mechanism $[10,11,104,105]$. This mechanism is fundamentally different from the superficial heat transfer of conventional heating. Therefore, noticeable advantages of microwave heating have been highlighted during the last few years. 


\subsection{Applying the Microwave in the Case of the HDO Processes}

The unique advantages of MWH establish this heating mechanism as an alternative to conventional heating $[\mathrm{CH}]$ in several applications. The mechanism of $\mathrm{MWH}$ relies on direct volumetric energy conversion, i.e., direct conversion of electromagnetic energy to heat energy within the volume of the heated material. This mechanism is fundamentally different from the superficial heat transfer of $\mathrm{CH}$ and, thus, can avoid most of the issues and limitations associated with $\mathrm{CH}$, which most importantly include the temperature gradient inside and outside the heated material. The interaction between microwaves and the heated material, mainly based on the material's dielectric properties, leads to selectively heating the target. This reduces the heat energy required to achieve a particular end, which consequently results in decreasing the operating costs as well as the potential of thermal hazards. In addition, it can restrict secondary reactions and might lead to (1) producing material with a novel microstructure, (2) initiating reactions that cannot be initiated when $\mathrm{CH}$ is applied, and (3) achieving the existing reactions under conditions that are different from those of traditional processing. Furthermore, numerous investigations have reported that $\mathrm{MWH}$ can save more in energy consumption and enhance product quantity and quality compared to the conventional processed materials [106-112].

Shekara C. et al. have documented that MWH achieves a better conversion compared to $\mathrm{CH}$ [106]. MWH modifies the porosity of the processed materials and leads to a faster reaction rate with less energy consumption compared to $\mathrm{CH}$, as claimed by Paixão and Monteiro et al. [107]. Patil, Gude et al. agree with Paixão and Monteiro et al. on the impacts of microwaves on the reaction rate [113]. A higher product yield in less reaction time has been reported by Zhang and Zhao [108]. Budarin and Clark et al. have investigated the influence of microwaves on product quality compared with conventional processes, which led to documenting that the obtained oil contains few impurities and is rich in aromatics [110]. Guiotoku and Rambo et al. tend to believe that MWH increases the carbonization yield [114]. MWH decreases catalyst loading and liquefaction according to Krzan and Zagar [115]. Dogan and Hilmioglu found that MWH significantly shortens the reaction time compared to the traditional methods [116]. Increasing the conversion was reported by Sithambaram, Nyutu et al. [117]. Orozco, Ahmad et al. are in agreement with the above-mentioned claims regarding the higher product yields, shorter reaction time, and higher reaction rate at a moderate temperature [118]. The same conclusion was reached by Lucchesi and Chemat et al., and Menéndez and Domínguez et al., 2004 [112,119]. Karthikeyan and Balasubramanian et al. believe that applying MWH leads to a faster extraction rate and produces different chemical components than $\mathrm{CH}$ [111]. Zhu and Wu et al. and Farag et al. have reported the noticeable impacts of MWH on enhancing product quality [104,120]. Further details about the nature of MWH are demonstrated in the references [11,121].

In summary, it is believed that applying MWH impacts reaction kinetics in addition to the noticeable effects on the product yield, product quality, and energy consumption. It should be noted that these key conclusions highly depend on the dielectric properties of each component of the target(s) and other aspects.

In the oil industry, most common feedstocks—namely, crude oils and gaseous components—are not active microwave receptors and, in turn, fail to establish substantial interaction with electromagnetic microwaves. On the other hand, most metals, metal oxides and catalytic agents are highly efficient microwave-to-heat converters. This aspect, which is a rather complicated matter in several applications, could revolutionize the industry. Having a high local temperature on the active site promotes catalytic and noncatalytic reactions while the undesirable secondary reactions was restricted due to the relatively low temperature of the bulk material(s). As a result, it is believed that the applications of the outstanding temperature gradient of microwave heating ameliorate not only the productivity but also the selectivity of various reactions in oil processing.

Coupling microwave heating with HDO technology would take advantage of this heating mechanism. Most importantly, it includes most of the catalysts that are usually applied in HDO processes, such as the transition metal catalysts, phosphide, carbide, and nitride catalysts, oxide catalysts, and sulphide catalysts, and the oxygenated compounds that exist in the oil are polar materials. 
This would act as a strong microwave-to-heat converter. On the other hand, petroleum oils have a relatively low level of interaction with microwaves. In contrast, the polar site containing oxygen in the oxygenated compounds inside the oil have a high level of interaction, which means the generation of heat energy is performed locally where the $\mathrm{C}-\mathrm{O}$ bond cleavage takes place. Polar compounds that exist in pyrolysis oil are strong microwave receptors.

Author Contributions: Writing—original draft preparation, M.A.; writing—review and editing, M.A.; supervision, J.C.; project manager, S.F. All authors have read and agreed to the published version of the manuscript.

Funding: This research received no external funding.

Conflicts of Interest: The authors declare no conflict of interest.

\section{References}

1. Vasilevich, A.V.; Baklanova, O.N.; Lavrenov, A.V. Hydrodeoxygenation of Guaiacol with Molybdenum-Carbide-Based Carbon Catalysts. ChemistrySelect 2020, 5, 4575-4579. [CrossRef]

2. Isahak, W.N.R.W.; Hisham, M.W.M.; Yarmo, M.A.; Hin, T.-Y.Y. A review on bio-oil production from biomass by using pyrolysis method. Renew. Sustain. Energy Rev. 2012, 16, 5910-5923. [CrossRef]

3. Rubin, E.M. Genomics of cellulosic biofuels. Nat. Cell Biol. 2008, 454, 841-845. [CrossRef]

4. Farag, S. Production of Chemicals by Microwave Thermal Treatment of Lignin. Ph.D. Thesis, University of Montreal, Montreal, QC, Canada, December 2013.

5. De Wild, P.J.; Huijgen, W.J.J.; Heeres, H. Pyrolysis of wheat straw-derived organosolv lignin. J. Anal. Appl. Pyrolysis 2012, 93, 95-103. [CrossRef]

6. Mu, W.; Ben, H.; Ragauskas, A.; Deng, Y. Lignin Pyrolysis Components and Upgrading-Technology Review. BioEnergy Res. 2013, 6, 1183-1204. [CrossRef]

7. Zakzeski, J.; Bruijnincx, P.C.A.; Jongerius, A.L.; Weckhuysen, B.M. The Catalytic Valorization of Lignin for the Production of Renewable Chemicals. Chem. Rev. 2010, 110, 3552-3599. [CrossRef]

8. Farag, S.; Chaouki, J. Economics evaluation for on-site pyrolysis of kraft lignin to value-added chemicals. Bioresour. Technol. 2015, 175, 254-261. [CrossRef]

9. Farag, S.; Chaouki, J. Technical and Economical Feasibility of Pyrolysis of Kraft Lignin. In Proceedings of the TechConnect Briefs, Washington, DC, USA, 14-17 June 2015.

10. Farag, S.; Fu, D.; Jessop, P.G.; Chaouki, J. Detailed compositional analysis and structural investigation of a bio-oil from microwave pyrolysis of kraft lignin. J. Anal. Appl. Pyrolysis 2014, 109, 249-257. [CrossRef]

11. Farag, S.; Kouisni, L.; Chaouki, J. Lumped Approach in Kinetic Modeling of Microwave Pyrolysis of Kraft Lignin. Energy Fuels 2014, 28, 1406-1417. [CrossRef]

12. Naik, S.; Goud, V.V.; Rout, P.K.; Dalai, A.K. Production of first and second generation biofuels: A comprehensive review. Renew. Sustain. Energy Rev. 2010, 14, 578-597. [CrossRef]

13. Sims, R.E.; Mabee, W.; Saddler, J.N.; Taylor, M. An overview of second generation biofuel technologies. Bioresour. Technol. 2010, 101, 1570-1580. [CrossRef]

14. Huber, G.W.; Iborra, S.; Corma, A. Synthesis of transportation fuels from biomass: Chemistry, catalysts, and engineering. Chem. Rev. 2006, 106, 4044-4098. [CrossRef]

15. Huber, G.W.; Dumesic, J.A. An overview of aqueous-phase catalytic processes for production of hydrogen and alkanes in a biorefinery. Catal. Today 2006, 111, 119-132. [CrossRef]

16. Demirbas, A.; Arin, G. An Overview of Biomass Pyrolysis. Energy Sources 2002, 24, 471-482. [CrossRef]

17. Demirbas, A. Biofuels securing the planet's future energy needs. Energy Convers. Manag. 2009, 50, 2239-2249. [CrossRef]

18. Attia, M.; Farag, S.; Habibzadeh, S.; Chaouki, J. Fast Pyrolysis of Lignocellulosic Biomass for the Production of Energy and Chemicals: A Critical Review. Curr. Org. Chem. 2016, 20, 1. [CrossRef]

19. Bridgwater, T. Fast pyrolysis of biomass for the production of liquids. Biomass Combust. Sci. Technol. Eng. 2013, 130-171. [CrossRef]

20. Attia, M.; Farag, S.; Jaffer, S.A.; Chaouki, J. Metal and sulfur removal from petroleum oil using a novel demetallization-desulfurization agent and process. J. Clean. Prod. 2020, 275, 124177. [CrossRef]

21. Shang, H.; Liu, Y.; Shi, J.-C.; Shi, Q.; Zhang, W.-H. Microwave-assisted nickel and vanadium removal from crude oil. Fuel Process. Technol. 2016, 142, 250-257. [CrossRef] 
22. Dedeles, G.R.; Abe, A.; Saito, K.; Asano, K.; Saito, K.; Yokota, A.; Tomita, F. Microbial demetallization of crude oil: Nickel protoporphyrin disodium as a model organo-metallic substrate. J. Biosci. Bioeng. 2000, 90, 515-521. [CrossRef]

23. Si, Z.; Zhang, X.; Wang, C.; Ma, L.; Dong, R. An Overview on Catalytic Hydrodeoxygenation of Pyrolysis Oil and Its Model Compounds. Catalysts 2017, 7, 169. [CrossRef]

24. Saber, M.; Nakhshiniev, B.; Yoshikawa, K. A review of production and upgrading of algal bio-oil. Renew. Sustain. Energy Rev. 2016, 58, 918-930. [CrossRef]

25. Jin, W.; Pérez, L.P.; Yu, J.; Odriozola, J.; Gu, S.; Reina, T. Cost-effective routes for catalytic biomass upgrading. Curr. Opin. Green Sustain. Chem. 2020, 23, 1-9. [CrossRef]

26. Hu, X.; Li, C.; Xu, Y.; Wang, Q.; Zhu, X. On the thermal oxidation stability of pyrolysis biomass oil. Int. J. Renew. Energy Technol. 2011, 2, 155. [CrossRef]

27. Valle, B.; Remiro, A.; García-Gómez, N.; Gayubo, A.G.; Bilbao, J. Recent research progress on bio-oil conversion into bio-fuels and raw chemicals: A review. J. Chem. Technol. Biotechnol. 2019, 94, 670-689. [CrossRef]

28. Fermoso, J.; Pizarro, P.; Coronado, J.M.; Serrano, D. Advanced biofuels production by upgrading of pyrolysis bio-oil. Wiley Interdiscip. Rev. Energy Environ. 2017, 6, e245. [CrossRef]

29. Pawar, A.; Panwar, N.L.; Salvi, B.L. Comprehensive review on pyrolytic oil production, upgrading and its utilization. J. Mater. Cycles Waste Manag. 2020, 22, 1712-1722. [CrossRef]

30. Mostafazadeh, A.K.; Solomatnikova, O.; Drogui, P.; Tyagi, R.D. A review of recent research and developments in fast pyrolysis and bio-oil upgrading. Biomass Convers. Biorefin. 2018, 8, 739-773. [CrossRef]

31. Liu, R.; Fei, W.; Shen, C. Influence of acetone addition on the physicochemical properties of bio-oils. J. Energy Inst. 2014, 87, 127-133. [CrossRef]

32. Jiang, X.; Ellis, N. Upgrading Bio-oil through Emulsification with Biodiesel: Mixture Production. Energy Fuels 2010, 24, 1358-1364. [CrossRef]

33. Kanhounnon, W.G.; Kuevi, U.A.; Kpotin, G.A.; Koudjina, S.; Houngue, A.K.; Atohoun, G.Y.S.; Mensah, J.-B.; Badawi, M. Quantum mechanistic study of furan and 2-methylfuran hydrodeoxygenation on molybdenum and tungsten sulfide clusters. J. Mol. Model. 2019, 25, 237. [CrossRef]

34. Sundqvist, T.; Oasmaa, A.; Koskinen, A. Upgrading Fast Pyrolysis Bio-Oil Quality by Esterification and Azeotropic Water Removal. Energy Fuels 2015, 29, 2527-2534. [CrossRef]

35. Weerachanchai, P.; Tangsathitkulchai, C.; Tangsathitkulchai, M. Effect of reaction conditions on the catalytic esterification of bio-oil. Korean J. Chem. Eng. 2012, 29, 182-189. [CrossRef]

36. Jo, H.; Verma, D.; Kim, J. Excellent aging stability of upgraded fast pyrolysis bio-oil in supercritical ethanol. Fuel 2018, 232, 610-619. [CrossRef]

37. Lee, J.-H.; Lee, I.-G.; Park, J.-Y.; Lee, K.-Y. Efficient upgrading of pyrolysis bio-oil over Ni-based catalysts in supercritical ethanol. Fuel 2019, 241, 207-217. [CrossRef]

38. Quan, C.; Xu, S.; Zhou, C. Steam reforming of bio-oil from coconut shell pyrolysis over Fe/olivine catalyst. Energy Convers. Manag. 2017, 141, 40-47. [CrossRef]

39. Lan, P.; Xu, Q.; Zhou, M.; Lan, L.; Zhang, S.; Yan, Y. Catalytic Steam Reforming of Fast Pyrolysis Bio-Oil in Fixed Bed and Fluidized Bed Reactors. Chem. Eng. Technol. 2010, 33, 2021-2028. [CrossRef]

40. Mortensen, P.M.; Grunwaldt, J.-D.; Jensen, P.A.; Knudsen, K.; Jensen, A.D. A review of catalytic upgrading of bio-oil to engine fuels. Appl. Catal. A Gen. 2011, 407, 1-19. [CrossRef]

41. Tanneru, S.K.; Steele, P.H. Direct hydrocracking of oxidized bio-oil to hydrocarbons. Fuel 2015, 154, $268-274$. [CrossRef]

42. Morales-Delarosa, S.; Campos-Martin, J. Catalytic processes and catalyst development in biorefining. Adv. Biorefin. 2014, 152-198. [CrossRef]

43. Dabros, T.M.; Stummann, M.Z.; Høj, M.; Jensen, P.A.; Grunwaldt, J.-D.; Gabrielsen, J.; Mortensen, P.M.; Jensen, A.D. Transportation fuels from biomass fast pyrolysis, catalytic hydrodeoxygenation, and catalytic fast hydropyrolysis. Prog. Energy Combust. Sci. 2018, 68, 268-309. [CrossRef]

44. Li, F.; Srivatsa, S.C.; Bhattacharya, S. A review on catalytic pyrolysis of microalgae to high-quality bio-oil with low oxygeneous and nitrogenous compounds. Renew. Sustain. Energy Rev. 2019, 108, 481-497. [CrossRef]

45. Zhang, L.; Liu, R.; Yin, R.; Mei, Y. Upgrading of bio-oil from biomass fast pyrolysis in China: A review. Renew. Sustain. Energy Rev. 2013, 24, 66-72. [CrossRef] 
46. Bridgwater, A.V. Review of fast pyrolysis of biomass and product upgrading. Biomass Bioenergy 2012, 38, 68-94. [CrossRef]

47. Li, N.; Tompsett, G.A.; Huber, G. Renewable High-Octane Gasoline by Aqueous-Phase Hydrodeoxygenation of $C_{5}$ and $C_{6}$ Carbohydrates over Pt/Zirconium Phosphate Catalysts. ChemSusChem 2010, 3, 1154-1157. [CrossRef]

48. Furimsky, E. Catalytic hydrodeoxygenation. Appl. Catal. A Gen. 2000, 199, 147-190. [CrossRef]

49. Pourzolfaghar, H.; Abnisa, F.; Daud, W.M.A.W.; Aroua, M.K. Atmospheric hydrodeoxygenation of bio-oil oxygenated model compounds: A review. J. Anal. Appl. Pyrolysis 2018, 133, 117-127. [CrossRef]

50. Marker, T.L.; Felix, L.G.; Linck, M.B.; Roberts, M.J. Integrated hydropyrolysis and hydroconversion (IH2) for the direct production of gasoline and diesel fuels or blending components from biomass, Part 1: Proof of principle testing. Environ. Prog. Sustain. Energy 2011, 31, 191-199. [CrossRef]

51. Regmi, Y.N.; Mann, J.K.; McBride, J.R.; Tao, J.; Barnes, C.E.; Labbé, N.; Chmely, S.C. Catalytic transfer hydrogenolysis of organosolv lignin using B-containing FeNi alloyed catalysts. Catal. Today 2018, 302, 190-195. [CrossRef]

52. Kim, S.; Kwon, E.E.; Kim, Y.T.; Jung, S.; Kim, H.J.; Huber, G.W.; Lee, J. Recent advances in hydrodeoxygenation of biomass-derived oxygenates over heterogeneous catalysts. Green Chem. 2019, 21, 3715-3743. [CrossRef]

53. Elkasabi, Y.; Mullen, C.A.; Pighinelli, A.L.; Boateng, A.A. Hydrodeoxygenation of fast-pyrolysis bio-oils from various feedstocks using carbon-supported catalysts. Fuel Process. Technol. 2014, 123, 11-18. [CrossRef]

54. Bu, Q.; Lei, H.; Zacher, A.H.; Wang, L.; Ren, S.; Liang, J.; Wei, Y.; Liu, Y.; Tang, J.; Zhang, Q.; et al. A review of catalytic hydrodeoxygenation of lignin-derived phenols from biomass pyrolysis. Bioresour. Technol. 2012, 124, 470-477. [CrossRef]

55. Elliott, D.; Neuenschwander, G. Liquid Fuels by Low-Severity Hydrotreating of Biocrude. In Developments in Thermochemical Biomass Conversion; Springer: Berlin/Heidelberg, Germany, 1997; pp. 611-621.

56. Elliott, D.C.; Oasmaa, A. Catalytic hydrotreating of black liquor oils. Energy Fuels 1991, 5, 102-109. [CrossRef]

57. Ly, H.V.; Kim, J.; Hwang, H.T.; Choi, J.H.; Woo, H.C.; Kim, S.-S. Catalytic Hydrodeoxygenation of Fast Pyrolysis Bio-Oil from Saccharina japonica Alga for Bio-Oil Upgrading. Catalysts 2019, 9, 1043. [CrossRef]

58. Schmitt, C.C.; Reolon, M.B.G.; Zimmermann, M.; Raffelt, K.; Grunwaldt, J.-D.; Dahmen, N. Synthesis and Regeneration of Nickel-Based Catalysts for Hydrodeoxygenation of Beech Wood Fast Pyrolysis Bio-Oil. Catalysts 2018, 8, 449. [CrossRef]

59. Centeno, A.; Laurent, E.; Delmon, B. Influence of the Support of CoMo Sulfide Catalysts and of the Addition of Potassium and Platinum on the Catalytic Performances for the Hydrodeoxygenation of Carbonyl, Carboxyl, and Guaiacol-Type Molecules. J. Catal. 1995, 154, 288-298. [CrossRef]

60. Laurent, E.; Delmon, B. Study of the hydrodeoxygenation of carbonyl, car $\square$ ylic and guaiacyl groups over sulfided $\mathrm{CoMo} / \gamma-\mathrm{Al}_{2} \mathrm{O}_{3}$ and $\mathrm{NiMo} / \gamma-\mathrm{Al}_{2} \mathrm{O}_{3}$ catalysts: I. Catalytic reaction schemes. Appl. Catal. A Gen. 1994, 109, 77-96. [CrossRef]

61. Laurent, E.; Delmon, B. Study of the hydrodeoxygenation of carbonyl, car $\square$ ylic and guaiacyl groups over sulfided $\mathrm{CoMo} / \gamma-\mathrm{Al}_{2} \mathrm{O}_{3}$ and $\mathrm{NiMo} / \gamma-\mathrm{Al}_{2} \mathrm{O}_{3}$ catalyst: II. Influence of water, ammonia and hydrogen sulfide. Appl. Catal. A Gen. 1994, 109, 97-115. [CrossRef]

62. Laurent, E.; Delmon, B. Influence of water in the deactivation of a sulfided $\mathrm{NiMo} / \gamma-\mathrm{Al} 2 \mathrm{O} 3$ catalyst during hydrodeoxygenation. J. Catal. 1994, 146, 281-291. [CrossRef]

63. Ferrari, M.; Maggi, R.; Delmon, B.; Grange, P. Influences of the Hydrogen Sulfide Partial Pressure and of a Nitrogen Compound on the Hydrodeoxygenation Activity of a CoMo/Carbon Catalyst. J. Catal. 2001, 198, 47-55. [CrossRef]

64. Jahromi, H.; Agblevor, F.A. Hydrodeoxygenation of Aqueous-Phase Catalytic Pyrolysis Oil to Liquid Hydrocarbons Using Multifunctional Nickel Catalyst. Ind. Eng. Chem. Res. 2018, 57, 13257-13268. [CrossRef]

65. Saidi, M.; Samimi, F.; Karimipourfard, D.; Nimmanwudipong, T.; Gates, B.C.; Rahimpour, M.R. Upgrading of lignin-derived bio-oils by catalytic hydrodeoxygenation. Energy Environ. Sci. 2014, 7, 103-129. [CrossRef]

66. Zhang, Y.; Monnier, J.; Ikura, M. Bio-oil upgrading using dispersed unsupported MoS2 catalyst. Fuel Process. Technol. 2020, 206, 106403. [CrossRef]

67. Wang, W.; Zhang, K.; Qiao, Z.; Li, L.; Liu, P.; Yang, Y. Influence of Surfactants on the Synthesis of MoS 2 Catalysts and Their Activities in the Hydrodeoxygenation of 4-Methylphenol. Ind. Eng. Chem. Res. 2014, 53, 10301-10309. [CrossRef] 
68. Yoosuk, B.; Tumnantong, D.; Prasassarakich, P. Amorphous unsupported Ni-Mo sulfide prepared by one step hydrothermal method for phenol hydrodeoxygenation. Fuel 2012, 91, 246-252. [CrossRef]

69. Bui, V.N.; Laurenti, D.; Afanasiev, P.; Geantet, C. Hydrodeoxygenation of guaiacol with CoMo catalysts. Part I: Promoting effect of cobalt on HDO selectivity and activity. Appl. Catal. B Environ. 2011, 101, 239-245. [CrossRef]

70. Yoosuk, B.; Tumnantong, D.; Prasassarakich, P. Unsupported $\mathrm{MoS}_{2}$ and $\mathrm{CoMoS}_{2}$ catalysts for hydrodeoxygenation of phenol. Chem. Eng. Sci. 2012, 79, 1-7. [CrossRef]

71. Bunch, A.Y.; Ozkan, U.S. Investigation of the Reaction Network of Benzofuran Hydrodeoxygenation over Sulfided and Reduced Ni-Mo/ $\mathrm{Al}_{2} \mathrm{O}_{3}$ Catalysts. J. Catal. 2002, 206, 177-187. [CrossRef]

72. Toba, M.; Abe, Y.; Kuramochi, H.; Osako, M.; Mochizuki, T.; Yoshimura, Y. Hydrodeoxygenation of waste vegetable oil over sulfide catalysts. Catal. Today 2011, 164, 533-537. [CrossRef]

73. Loricera, C.; Pawelec, B.; Infantes-Molina, A.; Álvarez-Galván, M.; Huirache-Acuña, R.; Nava, R.; Fierro, J.L.G. Hydrogenolysis of anisole over mesoporous sulfided CoMoW/SBA-15(16) catalysts. Catal. Today 2011, 172, 103-110. [CrossRef]

74. Yang, Y.; Gilbert, A.; Xu, C. Hydrodeoxygenation of bio-crude in supercritical hexane with sulfided CoMo and CoMoP catalysts supported on MgO: A model compound study using phenol. Appl. Catal. A Gen. 2009, 360, 242-249. [CrossRef]

75. Sepúlveda, C.; García, R.; Reyes, P.; Ghampson, I.T.; Fierro, J.L.G.; Laurenti, D.; Vrinat, M.; Escalona, N. Hydrodeoxygenation of guaiacol over $\mathrm{ReS}_{2} /$ activated carbon catalysts. Support and Re loading effect. Appl. Catal. A Gen. 2014, 475, 427-437.

76. Prasomsri, T.; Nimmanwudipong, T.; Román-Leshkov, Y. Effective hydrodeoxygenation of biomass-derived oxygenates into unsaturated hydrocarbons by $\mathrm{MoO}_{3}$ using low $\mathrm{H}_{2}$ pressures. Energy Environ. Sci. 2013, 6, 1732-1738. [CrossRef]

77. Gutierrez, A.; Kaila, R.K.; Honkela, M.; Slioor, R.; Krause, A. Hydrodeoxygenation of guaiacol on noble metal catalysts. Catal. Today 2009, 147, 239-246. [CrossRef]

78. Han, Y.; Gholizadeh, M.; Tran, C.-C.; Kaliaguine, S.; Li, C.-Z.; Olarte, M.; Garcia-Perez, M. Hydrotreatment of pyrolysis bio-oil: A review. Fuel Process. Technol. 2019, 195, 106140. [CrossRef]

79. Mendes, F.L.; Da Silva, V.T.; Pacheco, M.E.; Toniolo, F.S.; Henriques, C.A. Bio-oil hydrotreating using nickel phosphides supported on carbon-covered alumina. Fuel 2019, 241, 686-694. [CrossRef]

80. Gutiérrez-Rubio, S.; Moreno, I.; Serrano, D.P.; Coronado, J.M. Hydrotreating of Guaiacol and Acetic Acid Blends over $\mathrm{Ni}_{2} \mathrm{P} / \mathrm{ZSM}-5$ Catalysts: Elucidating Molecular Interactions during Bio-Oil Upgrading. ACS Omega 2019, 4, 21516-21528. [CrossRef]

81. López, M.; Hernández, D.; LaVerde, J.; Pérez, S.; Lopez, D. Catalytic Upgrading of Residual Biomass Derived Bio-oil over Molybdenum Carbide. Waste Biomass Valoris. 2019, 11, 2849-2856. [CrossRef]

82. Shu, R.; Li, R.; Lin, B.; Wang, C.; Cheng, Z.; Chen, Y. A review on the catalytic hydrodeoxygenation of lignin-derived phenolic compounds and the conversion of raw lignin to hydrocarbon liquid fuels. Biomass Bioenergy 2020, 132, 105432. [CrossRef]

83. Patil, M.L.; Lali, A.M.; Dalai, A. Catalytic hydrodeoxygenation of bio-oil model compound for production of fuel grade oil. Asia Pac. J. Chem. Eng. 2019, 14. [CrossRef]

84. Sergeev, A.G.; Hartwig, J.F. Selective, Nickel-Catalyzed Hydrogenolysis of Aryl Ethers. Science 2011, 332, 439-443. [CrossRef]

85. Basudeb, S.; Saha, B.; Luque, R. Hydrodeoxygenation processes: Advances on catalytic transformations of biomass-derived platform chemicals into hydrocarbon fuels. Bioresour. Technol. 2015, 178, 108-118. [CrossRef]

86. Climent, M.J.; Corma, A.; Iborra, S. Conversion of biomass platform molecules into fuel additives and liquid hydrocarbon fuels. Green Chem. 2014, 16, 516-547. [CrossRef]

87. Grilc, M.; Likozar, B. Levulinic acid hydrodeoxygenation, decarboxylation and oligmerization over $\mathrm{NiMo} / \mathrm{Al}_{2} \mathrm{O}_{3}$ catalyst to bio-based value-added chemicals: Modelling of mass transfer, thermodynamics and micro-kinetics. Chem. Eng. J. 2017, 330, 383-397. [CrossRef]

88. Rocha, A.S.; Souza, L.A.; Oliveira, R.R.; Rocha, A.B.; Da Silva, V.T. Hydrodeoxygenation of acrylic acid using $\mathrm{Mo}_{2} \mathrm{C} / \mathrm{Al}_{2} \mathrm{O}_{3}$. Appl. Catal. A Gen. 2017, 531, 69-78. [CrossRef] 
89. Zheng, H.; Zhu, Y.-L.; Teng, B.-T.; Bai, Z.-Q.; Zhang, C.-H.; Xiang, H.-W.; Li, Y.-W. Towards understanding the reaction pathway in vapour phase hydrogenation of furfural to 2-methylfuran. J. Mol. Catal. A Chem. 2006, 246, 18-23. [CrossRef]

90. Chen, G.; Liu, J.; Li, X.; Zhang, J.; Yin, H.; Su, Z. Investigation on catalytic hydrodeoxygenation of eugenol blend with light fraction in bio-oil over Ni-based catalysts. Renew. Energy 2020, 157, 456-465. [CrossRef]

91. Lin, B.; Li, R.; Shu, R.; Wang, C.; Yuan, Z.; Liu, Y.; Chen, Y. Synergistic effect of highly dispersed Ru and moderate acid site on the hydrodeoxygenation of phenolic compounds and raw bio-oil. J. Energy Inst. 2019, 93. [CrossRef]

92. Kumar, A.; Kumar, A.; Biswas, B.; Kumar, J.; Yenumala, S.R.; Bhaskar, T. Hydrodeoxygenation of m-Cresol over Ru based catalysts: Influence of catalyst support on $\mathrm{m}$-Cresol conversion and methylcyclohexane selectivity. Renew. Energy 2020, 151, 687-697. [CrossRef]

93. Mukundan, S.; Sriganesh, G.; Kumar, P. Upgrading Prosopis juliflora to biofuels via a two-step pyrolysis-Catalytic hydrodeoxygenation approach. Fuel 2020, 267, 117320. [CrossRef]

94. Bakhtyari, A.; Rahimpour, M.; Raeissi, S. Cobalt-molybdenum catalysts for the hydrodeoxygenation of cyclohexanone. Renew. Energy 2020, 150, 443-455. [CrossRef]

95. Bakhtyari, A.; Sakhayi, A.; Rahimpour, M.; Raeissi, S. Upgrading of cyclohexanone to hydrocarbons by hydrodeoxygenation over nickel-molybdenum catalysts. Int. J. Hydrogen Energy 2020, 45, 11062-11076. [CrossRef]

96. Eschenbacher, A.; Saraeian, A.; Shanks, B.H.; Jensen, P.A.; Li, C.; Duus, J.Ø.; Hansen, A.B.; Mentzel, U.V.; Henriksen, U.B.; Ahrenfeldt, J.; et al. Enhancing bio-oil quality and energy recovery by atmospheric hydrodeoxygenation of wheat straw pyrolysis vapors using Pt and Mo-based catalysts. Sustain. Energy Fuels 2020, 4, 1991-2008. [CrossRef]

97. Resende, K.; Noronha, F.; Hori, C. Hydrodeoxygenation of phenol over metal supported niobia catalysts. Renew. Energy 2020, 149, 198-207. [CrossRef]

98. Jacobson, K.; Maheria, K.C.; Dalai, A.K. Bio-oil valorization: A review. Renew. Sustain. Energy Rev. 2013, 23, 91-106. [CrossRef]

99. Cheng, S.; Wei, L.; Zhao, X.; Julson, J. Application, Deactivation, and Regeneration of Heterogeneous Catalysts in Bio-Oil Upgrading. Catalysts 2016, 6, 195. [CrossRef]

100. Furimsky, E. Deactivation of hydroprocessing catalysts. Catal. Today 1999, 52, 381-495. [CrossRef]

101. Cordero-Lanzac, T.; Palos, R.; Hita, I.; Arandes, J.M.; Rodríguez-Mirasol, J.; Cordero, T.; Bilbao, J.; Castaño, P. Revealing the pathways of catalyst deactivation by coke during the hydrodeoxygenation of raw bio-oil. Appl. Catal. B Environ. 2018, 239, 513-524. [CrossRef]

102. Bagnato, G.; Sanna, A. Process and Techno-Economic Analysis for Fuel and Chemical Production by Hydrodeoxygenation of Bio-Oil. Catalysts 2019, 9, 1021. [CrossRef]

103. Carrasco, J.L.; Gunukula, S.; Boateng, A.A.; Mullen, C.A.; DeSisto, W.J.; Wheeler, M.C. Pyrolysis of forest residues: An approach to techno-economics for bio-fuel production. Fuel 2017, 193, 477-484. [CrossRef]

104. Farag, S.; Mudraboyina, B.P.; Jessop, P.G.; Chaouki, J. Impact of the heating mechanism on the yield and composition of bio-oil from pyrolysis of kraft lignin. Biomass Bioenergy 2016, 95, 344-353. [CrossRef]

105. Samih, S.; Latifi, M.; Farag, S.; Leclerc, P.; Chaouki, J. From complex feedstocks to new processes: The role of the newly developed micro-reactors. Chem. Eng. Process. Process Intensif. 2018, 131, 92-105. [CrossRef]

106. Shekara, B.C.; Prakash, B.J.; Bhat, Y.S. Microwave-induced deactivation-free catalytic activity of BEA zeolite in acylation reactions. J. Catal. 2012, 290, 101-107. [CrossRef]

107. Paixão, V.; Monteiro, R.; Andrade, M.; Fernandes, A.; Rocha, J.; Carvalho, A.; Leitão, R.A.D.S.E. Desilication of MOR zeolite: Conventional versus microwave assisted heating. Appl. Catal. A Gen. 2011, 402, 59-68. [CrossRef]

108. Zhang, Z.; Zhao, Z.K. Microwave-assisted conversion of lignocellulosic biomass into furans in ionic liquid. Bioresour. Technol. 2010, 101, 1111-1114. [CrossRef]

109. Pan, R.; Wu, Y.; Wang, Q.; Hong, Y. Preparation and catalytic properties of platinum dioxide nanoparticles: A comparison between conventional heating and microwave-assisted method. Chem. Eng. J. 2009, 153, 206-210. [CrossRef]

110. Budarin, V.L.; Clark, J.H.; Lanigan, B.A.; Shuttleworth, P.; Breeden, S.W.; Wilson, A.J.; MacQuarrie, D.J.; Milkowski, K.; Jones, J.; Bridgeman, T.; et al. The preparation of high-grade bio-oils through the controlled, low temperature microwave activation of wheat straw. Bioresour. Technol. 2009, 100, 6064-6068. [CrossRef] 
111. Karthikeyan, S.; Balasubramanian, R.; See, S.W. Optimization and validation of a low temperature microwave-assisted extraction method for analysis of polycyclic aromatic hydrocarbons in airborne particulate matter. Talanta 2006, 69, 79-86. [CrossRef]

112. Lucchesi, M.E.; Chemat, F.; Smadja, J. Solvent-free microwave extraction of essential oil from aromatic herbs: Comparison with conventional hydro-distillation. J. Chromatogr. A 2004, 1043, 323-327. [CrossRef]

113. Patil, P.; Gude, V.G.; Pinappu, S.; Deng, S. Transesterification kinetics of Camelina sativa oil on metal oxide catalysts under conventional and microwave heating conditions. Chem. Eng. J. 2011, 168, 1296-1300. [CrossRef]

114. Guiotoku, M.; Rambo, C.; Hansel, F.; Magalhães, W.; Hotza, D. Microwave-assisted hydrothermal carbonization of lignocellulosic materials. Mater. Lett. 2009, 63, 2707-2709. [CrossRef]

115. Kržan, A.; Žagar, E. Microwave driven wood liquefaction with glycols. Bioresour. Technol. 2009, 100, 3143-3146. [CrossRef]

116. Dogan, H.; Hilmioglu, N.D. Dissolution of cellulose with NMMO by microwave heating. Carbohydr. Polym. 2009, 75, 90-94. [CrossRef]

117. Sithambaram, S.; Nyutu, E.K.; Suib, S.L. OMS-2 catalyzed oxidation of tetralin: A comparative study of microwave and conventional heating under open vessel conditions. Appl. Catal. A Gen. 2008, 348, 214-220. [CrossRef]

118. Orozco, A.; Ahmad, M.; Rooney, D.; Walker, G. Dilute Acid Hydrolysis of Cellulose and Cellulosic Bio-Waste Using a Microwave Reactor System. Process. Saf. Environ. Prot. 2007, 85, 446-449. [CrossRef]

119. Menéndez, J.; Domínguez, A.; Inguanzo, M.; Pis, J. Microwave pyrolysis of sewage sludge: Analysis of the gas fraction. J. Anal. Appl. Pyrolysis 2004, 71, 657-667. [CrossRef]

120. Zhu, S.; Wu, Y.; Yu, Z.; Liao, J.; Zhang, Y. Pretreatment by microwave/alkali of rice straw and its enzymic hydrolysis. Process. Biochem. 2005, 40, 3082-3086. [CrossRef]

121. Motasemi, F.; Afzal, M.T. A review on the microwave-assisted pyrolysis technique. Renew. Sustain. Energy Rev. 2013, 28, 317-330. [CrossRef]

Publisher's Note: MDPI stays neutral with regard to jurisdictional claims in published maps and institutional affiliations.

(C) 2020 by the authors. Licensee MDPI, Basel, Switzerland. This article is an open access article distributed under the terms and conditions of the Creative Commons Attribution (CC BY) license (http://creativecommons.org/licenses/by/4.0/). 